\title{
Phenomenology and Social Theory
}

Szanto, Thomas

Published in:

The Cambridge Handbook of Social Theory

DOI:

10.1017/9781316677445.016

Publication date:

2020

Document version

Early version, also known as pre-print

Citation for published version (APA):

Szanto, T. (2020). Phenomenology and Social Theory. In P. Kivisto (Ed.), The Cambridge Handbook of Social Theory (pp. 292-316). Cambridge University Press. https://doi.org/10.1017/9781316677445.016 
Forthcoming in: Peter Kivisto (Ed.). The Cambridge Handbook of Social Theory. Cambridge:

Cambridge University Press.

Please Refer to the Published Version

\title{
Phenomenology and Social Theory
}

\author{
Thomas Szanto
}

\section{Introduction}

Phenomenology is not so much an exact methodological doctrine as the title of a family of ideas, which originate in the work of the founder of the so-called phenomenological movement, Edmund Husserl. A common denominator that all authors from the phenomenological movement converge upon is that phenomenology is the study of phenomena of conscious experience from the first-person perspective. To be sure, 'phenomena of conscious experience' is a maximally broad denominator. It includes such diverse objects of study as the perception of ordinary spatio-temporal objects, scientific theories and knowledge systems, the experiential relation to one's own and others' mental states, emotions, space and temporality, values, norms or aesthetic objects and, not least, intersubjective relations, interaction, social facts and different types of social formations. Furthermore, a central explanandum of phenomenology is the everyday experience of such phenomena, or, to introduce a key notion of classical phenomenology, the 'life-world' of the experiencing subjects in which these phenomena are always and already embedded. A core contention of phenomenologists is that an adequate study of all these phenomena must take its cue from the analysis of the different aspects and modes in which they are given in subjective experience. For example, not only can I perceive the scenery in front of me, I can also imagine or remember it. I can wish or hope that what I see lasts. I can be directed at it with joy or dread. Moreover, I always grasp only parts or aspects of it. But however I am directed at an object or event, it will always and only be from a certain perspective, and it will always and only be from my own subjective perspective. Moreover, no matter what kind of experience and under what aspects we consider them, there will always be something or other that one is experiencing. In phenomenological jargon, in every experience, I am always intentionally directed 
at something or someone, and the respective intentional object of my experience is given to me always and only in certain modes of givenness. Putting these two ideas together, we can say that phenomenology studies the complex ways in which something is intentionally given in subjective conscious experience. Now prima facie this seems to lead not only to some kind of subjective relativism but, even more threateningly, to a form of solipsism. After all, one might argue, if the prime object of study is supposed to be the very way in which entities are given in first-person experience, how do we get from there to any claims about social reality or how do we integrate others' perspectives into the picture. Such skepticism has been voiced over and over again vis-à-vis classical phenomenology from countless and in many ways not unsympathetic thinkers of the 20th century, such as the critical theorists Adorno, Apel or Habermas (cf. Bernstein 1978; Wolff 2012; Zahavi 2000; Schmid 2001), or poststructuralists such as Foucault (cf. Oksala 2012). It canvasses, however, a wrong picture, as I shall argue in the following.

I will start by outlining the historical context and the meta-theoretical and more general socio-ontological issues explored in the phenomenological movement (sec. 1). I will then focus on two different dimensions of sociality that have been analyzed in detail by phenomenologists, notably dyadic, interpersonal, or intersubjective relations on the one hand (sec. 2) and the communal or collective dimension on the other (sec. 3). Regarding the first dimension, I will discuss phenomenological conceptions of empathy (sec. 2.1), socio-communicative acts and the issue of social typification (sec. 2.2), as well as the notion of the life-world (2.3). Regarding the phenomenology of community, I shall concentrate on phenomenological accounts of different social formations (sec. 3.1), collective intentionality (3.2) and shared emotions (3.3).

\section{Social Theory and the Phenomenological Movement}

\subsection{A Brief Historical Exposition}

Ever since its inception in the work of Husserl, phenomenology was directly engaged with a detailed analysis of social reality but also with contemporary thinking about social reality, or social theory. The phenomenological movement not only evolved side by side with classical sociology; rather, it was deeply interlinked with social thought, and especially so in the first three decades of the 20th century. Not only was Husserl fairly well acquainted with the work of the founding fathers of German sociology, Tönnies and Simmel; from very early on in his

thinking, around 1905, Husserl came to identify intersubjectivity — a term that 
was probably first coined by him — as one of the central tenets phenomenology must address. Husserl's subsequent plea for a 'phenomenological' or 'intentional sociology' (1916-1937: 389; cf. 1905-1920) did not go unheard by second- and third-generation phenomenologists. The most prominent examples pursuing this are: Max Scheler's sociology of knowledge (1924), his first systematic elaboration of the distinction between empathy, sympathy, emotional contagion and emotional sharing, and his axiological theory of social formations such as associations, life-communities or so-called communal persons (Gesamtperson) (1926a; 1926b); Alfred Schütz' critical engagement with Weber, Mead and Parson in his interpretive sociology (verstehende Soziologie) (1932), and its later development in the work of Peter Berger and Thomas Luckmann exploring the social construction of reality (1966); or Heidegger's famous analysis of Dasein as 'Being-with' (Mit-Sein) (1927), which was geared critically against his teacher's, Husserl's, theory of intersubjectivity and empathy. But beyond these better-known exponents, there were a number of second-generation phenomenologists who also engaged in booklength treatises on social ontology. Most of them began their studies of Husserl under Theodor Lipps, Moritz Geiger, Alexander Pfänder and Scheler in Munich and eventually established the so-called Göttingen Circle in 1907 around Husserl (cf. Spiegelberg 1982; Salice 2016a). They included Adolf Reinach, who developed a systematic theory of so-called social acts, such as orders or promises, which can be viewed as the first accounts of speech acts avant la lettre (1913); Edith Stein, who wrote her famous dissertation on empathy under Husserl (1917) and subsequently authored one of the most intriguing treatises on the relation between individuals and collectives and the 'experiential life' of communities (1922); and Gerda Walther (1923), whose dissertation on the ontology and affective life of communities is one of the finest pieces of phenomenological social ontology (cf. Zahavi \& Salice forthcoming; León \& Zahavi 2016; Szanto forthcoming). But one should also mention Dietrich von Hildebrand's intriguing treatise on the metaphysics of communities (1930; cf. Salice 2016b) and the hardly known Japanese phenomenologist and law scholar Tomoo Otaka who also developed a systematic ontology of social formations (1932). Other secondgeneration phenomenologists who have dealt extensively with the philosophy of social science from a phenomenological perspective include Felix Kaufmann (1944) and Aaron Gurwitsch (1931), who started their careers in Vienna and then emigrated to assume positions at the New School for Social Research in New York to become, along with their colleague Schütz, leading figures of the North American school of phenomenological sociology (see Barber 2004). ${ }^{1}$

\footnotetext{
${ }^{1}$ See the volume of Salice \& Schmid 2016 in which contributors explore all these and a number of other figures, such as Hermann Schmalenbach, Roman Ingarden, or Karl Löwith, in detail. See Szanto \& Moran 2016 for essays on the social phenomenology of, among others, Hannah Arendt, Dietrich von Hildebrand, Emmanuel Levinas, Adolf Reinach or Aaron Gurwitsch.
} 
Phenomenology, however, was never merely an ontological, epistemological or even just purely philosophical enterprise. In contrast to much of today's standard social philosophy and, in particular, contemporary social ontology in the analytic tradition (see sec. 3; cf., however, Pettit 1997 and Gilbert 2006), phenomenologists were interested not only in sociology but also in social renewal and political thought. Many were directly engaged in concrete social movements, and a number of representatives may readily be described as "phenomenologists engage' (Gubser 2014, 1). We should list here work on ethical renewal (Husserl), educational reform and early feminist thought (Stein), a sort of Catholic 'communitarianism' of the interwar period (e.g., Scheler, Stein or Hildebrand), phenomenological Marxism (e.g., Sartre, Enzo Paci, Karel Kosík or Trân Duc Thao), or postwar anti-(Soviet)-Communism (Merleau-Ponty (1955) or Patočka). ${ }^{2}$

\subsection{The Central Issues: From Individualism to Collectivism and Social Constructivism}

A good way to enter into phenomenological thinking about social reality is by way of distinguishing some general claims about the ontology and normative status individuals hold within social reality. The first three claims, which under different guises have been much debated throughout centuries of thinking from Aristotle to Marx or Durkheim, concern the issues of (i) individualism versus holism, (ii) singularism versus anti-singularism and (iii) collectivism versus anti-collectivism (cf. Pettit 1993, 2014). And there is a further corollary issue concerning the social constitution of reality, knowledge and truth, namely the issue of (iv) social constructivism.

(i) The first issue concerns the fundamental question of what constitutes or determines individual persons' mental, practical and emotional life or, broadly speaking, intentional psychology. The question is whether individuals' experiences, volitions, intentions or emotions are constitutively dependent on entertaining relations with other individuals or social relations (including for example interaction, collaborative or joint agency, affective sharing, communication or discursive thinking). An important epistemological corollary to this ontological issue is whether individuals can fully understand themselves and are understandable to others only by reference to those social relations. Or are there, rather, some essential features of human psychology whose existence and functioning are independent of persons being embedded in social relations (which, to be sure, is a contingent matter of fact of human existence)? Individualists endorse the latter

\footnotetext{
2 On phenomenological Marxism, see Smart 1976; Waldenfels et al. 1977ff.; Gubser 2014, and Thonhauser \& Schmid forthcoming. For concise general discussions of phenomenology's contribution to social theory, see also Mulligan 2001; Overgaard \& Zahavi (2009), and Ferguson 2006, chap. 4.
} 
claim, while holists deny it, and it is safe to say that virtually all phenomenologists endorse some version of holism. Just to mention a few representatives, and anticipating the discussion of empathy below, early phenomenologists such as Husserl, Scheler or Stein hold that the very personhood of individuals is co-constituted by the reciprocal and interpersonal relation that characterizes empathic encounters. And even for phenomenologists such as Heidegger or Sartre who have criticized or haven't made use of the concept of empathy, but have introduced the notions of 'Being-with' (Mit-Sein) or 'Being-for-Others' (Sartre 1943), being a person or Dasein is essentially entertaining interpersonal relations (cf. Koo 2016).

(ii) The next issue concerns the social atoms and the possible socioontological taxonomy of reality. Does social reality comprise only individual persons and their relations? Or does the ontology of the social world also include other social entities, including collectives or possibly 'higher-order' or 'supraindividual' entities, such as group agents or group persons? And, if the latter, do such non-individual agents have an intentional, mental or affective life of their own (group mentality, collective experiences, etc.), or a normative status (e.g., concerning collective responsibility) that is not reducible to but may still be founded upon individuals and their interactions? Though some have voiced skepticism (e.g. Schütz 1957; Kaufmann 1944), many authors from the phenomenological tradition such as Husserl, Scheler, Stein, Walther or the later Sartre have explored the latter possibility and endorse Socio-Ontological Anti-Singularism (see below sec. 2 and 3).

(iii) It is crucial to distinguish anti-singularism from anti-collectivism, all the more so since these two claims are prima facie in tension. The third main socioontological claim concerns the ontological and normative relation between individuals and non-individual social entities and social facts. Assuming antisingularist leanings, the issue is whether one is committed to the further-reaching claim that individuals' intentional psychology, behaviour, personhood or moral status (including their autonomous agency, spontaneity, moral accountability, dignity, etc.) are compromised, or, as Pettit (1993) aptly puts it, 'outflanked' or 'overridden', by individuals' membership in collectives, their shared affective life, intentional regularities governing group agency or sociocultural laws or norms. While this is indeed endorsed by for example Durkheim or different Marxist and some poststructuralist thinkers, there is hardly any phenomenologist who subscribes to such collectivism. ${ }^{3}$ A further issue in this connection concerns what Scheler discusses under the heading of "causal" and "value collectivism". According to value collectivism a person's value is to be measured against her contribu-

\footnotetext{
${ }^{3}$ Exceptions include, to be sure, some of the above-mentioned Marxist phenomenologists. When it comes to Sartre the matter is somewhat complicated. On the one hand, his earlier existentialist decisionism or voluntarism is certainly anti-collectivist in spirit; however, his later work certainly has some collectivist sympathies (see more below sec. 3.2).
} 
tion to a collective. According to "causal collectivism" a person's value is to be measured against the value of the historical development of communities. Scheler rejects both versions, to be sure (Scheler 1926a: 495-496; see more in sec. 3.1, and Szanto 2016b).

(iv) So much then for the ontological and normative space individuals and groups of individuals hold within social reality. What about claims concerning the social constitution or construction of reality as such? The decisive difference in the socio-ontological impact of these two issues, i.e. the (social) construction of social reality and the social construction of reality, is nicely reflected in the title of two books, the first representing the (Schutzian) phenomenological heritage by Peter Berger and Thomas Luckmann (1966), the other written by the analytic philosopher John Searle (1995). While Searle's book is one of the most influential contemporary social ontologies, concerned with how social facts such as money, marriages, institutions or conventions are constituted by acts of collective intentionality and acceptance, Berger and Luckmann provide arguably the clearest account of the sociology of knowledge tradition, whose founding text was published by Scheler (1924). However few phenomenological representatives it produced in the end, this tradition can still be seen as the most influential explicit phenomenological contribution to sociology.

Sociology of knowledge is "concerned with the analysis of the social construction of reality" (Berger \& Luckmann 1966: 15). But this analysis is inseparable from that of the social nature of knowledge of reality. Hence, for sociologists of knowledge the issue of the social nature of reality is never just an ontological but always also an epistemological and sociological enterprise. Knowledge is here defined as the "certainty that phenomena are real" (ibid., 13). Phenomena have the specific qualities they have independent of our individual stances and volitions. However, the key contention of sociologists of knowledge is that phenomena are not independent but relative to the social context and framework in which we conceptualize them or understand what their reality means for us. Accordingly, sociology of knowledge addresses how we individually or collectively come to see reality as objective, i.e., viewed from different perspectives other than mine or ours; how my everyday life-world is essentially not just mine but an intersubjective world that I share with certain but not all others; how bodily interaction, linguistic communication, institutionalization and conventional or normative legitimization play a role in such sharing; how all my experiences are embedded in and shaped by norms, habits and traditions of thinking, feeling and communicating; and how this social history and reality eventually becomes sedimented not only in objective systems of representation (symbolic signs, public discourse, etc.) but also via processes of subjective internalization, and thus ultimately constitutes my social and personal identity (as a social being). 
Surely, when it comes to the metaphysical plausibility of these and related claims, everything depends on how exactly to understand the notions of construction, constitution, or (in)dependence. Scheler, for example, clearly distinguishes between two different factors that regulate the acquisition of knowledge of reality, namely "ideal" and "real factors" (Ideal- and Realfaktoren). Real factors consist of the causal and material determinants of knowledge, such as the economic or demographic situation or power relations in society, as well as psychosocial and 'psycho-biological" ones, such as individual "instincts", "collective interests" and "drives". These factors are studied by (social) psychology, ethnology and sociology and determine the conditions under which certain forms of knowledge emerge or certain aspects of reality become visible to certain groups. But real factors only affect the historical emergence or actualization of the ideal factors in a given society. The latter consist of the set of spiritual or cultural achievements, values, religious ideas and normative ideals, or the Lebens- and Weltanschaunng. Real factors do not affect the content of these idealities. Consequently, Scheler rejects what he calls sociologism (Soziologismus), a form of Durkheimian social determinism. Instead, he advocates a co-determination between mind, knowledge and society. ${ }^{4}$ Scheler argues that only the "forms" of cognition, perception and knowledge and "the selection of objects of knowledge" are codetermined (mitbedingt) by the structure of society and its "dominant perspective of social interests" (Scheler 1924, 45). For the conservative Scheler, the latter is represented by the interests of the creative minority of pioneers and elites, and imitated and followed by the masses (ibid., 9). In opposition to Durkheimian sociologism, socio-economic, material or real social factors do not determine the epistemic content, let alone epistemological validity, of thoughts or theories (ibid., 57-58). Scheler thus follows the Marxist idea according to which there are certain class or other socio-economic and cultural factors that deeply shape the apperception of reality. Furthermore, he maintains that there are certain forms of thought and indeed affective patterns (esp. 1926a, 1926b) that are dependent on certain types of groups in which they alone can be realized. However, like most classical phenomenologists, he does not go so far as to identify most human thinking with a form of ideology (as the other key figure of the sociology of knowledge, Karl Mannheim, would in some readings; cf. Berger \& Luckmann 1966, 19-22; Staude 1967, 180-188). Rather, he retains the transcendentalphenomenological idea that there are a priori forms of reasoning and essential mental structures that are independent of any social factors (and this does not apply only to logical and mathematical thinking).

\footnotetext{
${ }^{4}$ This concept is similar to his later concept of the $c o$-responsibility of individuals for their lifecommunity or collective and conversely of the 'communal person' (Gesamtperson) for its members; see below and Szanto 2016b.
} 
However much Scheler, Berger and Luckmann and other phenomenologists with either stronger realist or idealist inclinations differ, most phenomenologists can readily agree on the following nuanced view regarding the issue of social constructivism: Reality is not constructed or causally dependent on human thinking and agency. However, it is also not just one-even if central- "portion of the real world", the one consisting of social facts, socially constituted, as Searle puts it (1995: 1); rather, the very sense that 'real' facts have in our everyday experience and how we share this everyday experience with others, or the very sense in which phenomena are taken to be real by us, is constituted and epistemologically depends on our social engagements. But if this is true, we cannot understand what 'reality as such' is supposed to be as long as we don't understand the sense in which human beings' sense of reality and their very being as persons and agents (see issue i) is intrinsically grounded in their social life-world. Put differently, phenomenologists are not committed to radical constructivism according to which everything, including ourselves, is but a social construct. However, they would still argue that we cannot fully understand reality as such or ourselves as long as we don't understand their essentially social nature (see also Collin 1997).

To summarize, phenomenology operates with a holistic, anti-singularist, but also anti-collectivist ontology and maintains a moderate, epistemological version of social constructivism. In the following I will try to bring into greater relief this still very general and abstract picture. Roughly, the idea is this: Individuals not only stand in interpersonal relations, which constitute their very being as persons and are characterized by their own type of experience, namely empathic experience (Einfüblung). They can also properly speaking share intentions, plans, values, and even affective states and, though interpersonal, empathic encounters lie at the bottom of such sharing, they are not sufficient for such plural or 'weexperiences'. Finally, depending on what exactly is shared (interests, volitions, emotions, etc.) and how robust the integration of the individuals is, phenomenologists distinguish different social formations.

\section{The Phenomenology of Empathy and Intersubjectivity}

As we have seen, phenomenology studies phenomena as they are given in subjective experience. Among the phenomena that arguably pervade subjective experience most deeply are other subjects and their experiences. Thus, the phenomenology of intersubjectivity, the analysis of the ways in which subjects are given to one another in experience, understand each other and interact, is not just one among others but a fundamental part of phenomenology. According to phenomenologists, subjects would not be full-fledged persons if they did not engage in interpersonal relations, and hence phenomenologists' endorsement of holism. But 
how do subjects first enter into and eventually maintain interpersonal relations? And how do they have access to each other's experiences and their mental, practical or affective life? Most classical phenomenologists' answer is that we access or experience other people by way of empathy (Einfühlung), interaction, social typification and so-called socio-communicative acts.

\subsection{Empathy, Interpersonal Understanding and Interaction}

The notion of empathy dates back to 19th century German aesthetics, when it was introduced to refer to the ability to 'feel oneself into' (Ein-fühlen) works of art (Vischer 1873). But its now standard association with interpersonal relations can be traced back to the work of the Munich psychologist and philosopher Lipps (1907, 1909). Ever since the controversy between Lipps and the early phenomenologists, especially Husserl and Stein, it is still very much contested what empathy exactly amounts to (cf. Michael 2014). However, there are roughly five features of what an empathic encounter between two persons amounts to, which all phenomenologists can agree upon and which were detailed especially by Husserl, Scheler and Stein.

(i) First, empathy is a sui generis kind of intentional act. That is, though empathic acts share some aspects with other kinds of mental acts, such as perception or imagination, they cannot be reduced to or explained by the latter. (ii) Secondly, the most basic form of empathy presupposes the face-to-face encounter of embodied agents. (iii) Third, some hold that there are different, more or less cognitively demanding forms of empathic understanding that resemble an imaginative envisaging of the mental or affective states and actions of others from their own perspective. But the most basic form of empathy is the direct apperception of other embodied minds. Furthermore, most allow for a rather complex but at the same time very common form of empathy that involves a certain reciprocity in empathizing, namely so-called iterative and reflexive empathy (e.g., Stein 1917). In iterative empathy, a subject A's empathic act $\mathrm{E}_{1}$ encompasses another subject $\mathrm{B}^{\prime}$ s empathic act $\mathrm{E}_{2}$, where $\mathrm{E}_{2}$ might be directed at another, thirdparty subject, or, as in reflexive empathy, at A herself. (iv) Fourth, phenomenologists have a clear view of how empathy relates to affectivity and emotions, a view that differs markedly from both the folk-psychological and dominant contemporary understanding of the notion. They argue that empathy must be clearly distinguished from related but distinctly different affectively laden interpersonal acts, such as emotional contagion, compassion or sympathy. Moreover, empathy is neither itself an emotion, nor does it either require some "affective similarity" between the empathizer's affective states and that of the target (Jacob 2011) or amount to any form of emotional sharing or 'emotional identification'- 
Einsfühlung, as Scheler aptly coins it in contradistinction to Einfühlung (Scheler 1926a; Stein 1917; cf. Zahavi \& Rochat 2016; Schloßberger 2016; see also sec. 3.3). (v) Finally, the more abstract phenomenological accounts of face-to-face empathic relations are typically accompanied by considerations of how such encounters are embedded in and mediated by the broader social context, involving social typification, direct interaction or collaboration. Let me just say a few words about these features and in the next section focus especially on the last point in some more detail, since it has the most direct impact on sociological considerations (see more in Jardine \& Szanto 2017).

In one of the most systematic classical phenomenological accounts of empathy, Stein defines empathy as "the experience of foreign subjects and their lived experience" (Stein 1917: 5, 20). This type of experience is a sui generis experience in that it is unlike imagination, but also unlike any kind of 'projection' of one's own past experiences or one's self-experience onto others. After all, there is surely a difference in grasping another person's sadness and feeling sad oneself or remembering the experiences of sadness one previously felt. Moreover, the access to and understanding of the motives, reasons or intensity of the sadness of another is surely different from the affective experience one might have if upon encountering another's sadness one eventually feels compassion with the other and in this sense comes to share another's sadness or sympathises with it. Rather than being identical, the latter experiences presuppose the former.

This general picture has a number of significant consequences for mainstream contemporary accounts of social cognition. Phenomenology challenges its core claims and assumptions that are as prevalent today as they were at the beginning of the $20^{\text {th }}$ century (esp. for Lipps). ${ }^{5}$ To begin with, the phenomenological account stands in marked contrast to a dominant view in current social cognition research according to which empathy is "caused by sharing the emotions of another person" or the "simulation of the feelings of others" (Hein \& Singer 2008). As indicated, phenomenology also opposes the similar and influential view according to which empathy is an affective state and requires "interpersonal similarity" between empathizer and target (Jacob 2011; De Vignemont \& Jacob 2012; cf. critically Zahavi 2011). Furthermore, it undermines the basic assumptions that constitute the fault line in the by now somewhat deadlocked so-called 'theory of mind' or 'mindreading' debate (e.g., Davies \& Stone 1995a, 1995b; Coplan \& Goldie 2011; Decety 2012; Baron-Cohen et al. 2013, Stueber 2013; Michael 2014; Zahavi 2014). Here, on the one hand we have those who argue that in order to access other minds we are explicitly simulating or imitating (e.g., Heal 1995; Goldman 2006; Stueber 2006; Gordon 2008) or sub-personally mirroring

\footnotetext{
${ }^{5}$ For some contemporary phenomenologically inspired accounts, see e.g. Ratcliffe 2007; Gallagher 2008a, 2008b; Krueger \& Overgaard 2012, and Zahavi 2014.
} 
(Gallese 2001) others' experiences in ourselves. Proponents of this theory are usually called simulation theorists. On the other hand, we have the 'theorytheorists', who claim that in grasping other minds we must engage in some conceptual, inferential and interpretative activity of mindreading. We do this by applying a folk-psychological theory of mind (operating with such concepts as intentions, desires, volitions, etc.), which we gradually learn to apply to ourselves and eventually project onto others (Leslie 1987; Gopnik \& Wellman 1992; Meltzoff \& Gopnik 1993; Baron-Cohen 1995; Leslie et al. 2004). Those who are not satisfied with either of these accounts often see no other alternative than to employ some so-called 'hybrid' strategy and describe empathizing as a sort of simulating-cum-projecting mental model that we apply to ourselves and others (Nichols \& Stich 2003). But as we have seen, phenomenologists argue that empathy is a sui generis experience in which we directly experience others' mental states, namely by perceiving embodied minds in action and expression, as it were. In contrast to this, the second core assumption that is presupposed in almost all standard theories, and has certainly fueled the theory of mind debate, is that we cannot directly perceive or be immediately aware of other minded persons (and animals), but only their external behaviour or bodies (cf. Stein 1917: 26). But a core claim of phenomenology is precisely that we are not first aware of inanimate bodies whose mental life lies somehow hidden behind their skull and skin; the relationship between body and mind is taken not as some mysterious link between two separate entities that empathy is supposed to first establish, but as an already expressive relation. In this sense, others' bodily gestures and movements are not just expressions of but fields of expression literally embodying mindedness (Scheler 1926a: 232258; Stein 1917: 61-68, 75-84). As Husserl puts it, the "body [...] is indeed expression of the mind and is at once organ of the mind" (1912-1916: 102). In an obvious sense, other minds are not in the same sense directly perceptible-we only literally 'see' other bodies. However, the conclusion that other minds are inherently invisible only follows from the assumption that the body is a meaningless physical entity. Once we appreciate that foreign bodies are directly visible as organs of the mind, the assumption loses its force.

But it's not just embodied minds that we deal with in our everyday experience of others. Indeed, when encountering others, we always and already encounter 'alter egos', as Husserl usually puts it, or full-fledged personal agents, who also recognize us as persons and agents and who are embedded in a specific social context that we typically share to a large extent. We do not merely perceive the other person's bodily countenances and gestures but rather see such movements as manifestations of the other's affective states, emotional dispositions or character traits ('The grumpy old man, he is angry again', etc.). Often, they are also expressive of the person's reasons for actions. This involves quasi-imaginatively repre- 
senting the situation 'as if I were the other, taking into account the other's values, habits, beliefs and goals, and thereby understanding how the other's situation would lead the other to act. As Husserl emphasizes, this is quite different from simply imagining how I would act in the other's situation (Husserl 1915-1917: 755759). Moreover, typically, we not only observe others but stand in communicative and practical interaction, coordinate our actions or collaborate to achieve a shared goal. Such shared practical contexts give each of us further cues as to the intentions of the other, which often would not otherwise be available. For example, if I see that a stranger in the bus suddenly stands up, walks towards me, smiles and reaches for the handles of the baby carriage I am trying to set down on the sidewalk, I will immediately understand that he wants to help me and need no further evidence or inference (cf. Butterfill 2011). ${ }^{6}$

Gurwitsch has explored such collaborative contexts in terms of "beingtogether in a common situation" and, in particular, in a situation of "partnership" of coordinated action or a "consociate being together" (gebundene Zusammensein). According to Gurwitsch, simply by being assigned and grasping the role you play, or being an active participant in a situation, and perhaps coordinating your actions with others, cooperating in achieving a joint goal, you gain an immediate understanding of others' roles. This in turn permits a richer understanding of others' desires, motivations, and intentions, since it familiarises you with the context of "relevance" (Schütz 1932; Schutz 1970; Schutz \& Luckmann 1974), which is specific to the situation and guides the intentions and motives of the agents. You thus gain a 'view from within', that is, from within a situation of being together.

While one confers with his partner, he faces the wishes, aims, and interests of the partner, which, even when not explicitly expressed, are provided by the setting of the things. In virtue of the partner's comportment during the negotiations, his aims, motivations, etc., can be discovered. One orients his comportment with respect to the position disclosed by his partner [...] As a result, one's own comportment in the situation (Situationsverbalten) is tuned in on the other and takes account of him. (Gurwitsch 1931: 105)

To be sure, often in our daily encounters with others, we remain satisfied if the other is empathetically grasped merely in accordance with "the general types of human existence” (Husserl 1915-1917: 580, 578). But even such a crude apperception of the other as a human being 'like me' is, as phenomenologists have shown, based on a complex, implicit or habitualized scheme of social typification.

\footnotetext{
${ }^{6}$ Recently, some authors drawing on these insights from the phenomenological tradition have endorsed what might be called the 'interactive turn' in social cognition, placing the emphasis on interacting social cognizers jointly 'enacting' on their environment; see esp. Gallagher 2001; 2008; Fuchs \& de Jaegher 2009; De Jaegher et. al. 2010; cf., critically, Overgaard \& Michael 2013; Michael et al. 2014.
} 


\subsection{Social Typification and Socio-Communicative Acts}

An important issue that has arguably not been sufficiently recognized in contemporary discussions of social cognition concerns the central role played by social typification in empathy, an issue explored at length in the phenomenological sociology of Schütz. Schütz has convincingly argued that in all actual cases of interpersonal encounter more or less explicit and specific typification of others will be at play. There is a complex "stratification" of interpersonal relationships, with "a continuous series of ever increasing anonymization, beginning with the ideal type 'my friend N' and culminating in the most general ideal type 'one' or 'someone' (Man), the originator of artifacts and objective sign systems" (1932: 219). On the most general level, social reality is stratified by the ways in which interpersonal relations can come about: either by direct experience and interaction with one another or by non-direct forms of inferentially being related to others. More specifically, Schütz distinguishes the following layers of social reality according to the type of interpersonal relationships. First we have "Thou-relationships" or "Thou-orientation" (Du-Beziehung, Du-Orientierung). Here others emerge in my immediate actual surrounding, and I am directed to them by means of empathy or acts of grasping foreign experiences (Fremdverstehen); if these empathic encounters are actual and reciprocal, the I-Thou relation constitutes a "we-relationship" (Wir Beziehungen). But not all social relations are direct face-to-face encounters of "consociates" (Mitmenschen), where subjects share their direct surrounding world (Umwelt) in "a here and now". Within the "social world of contemporaries" (soziale Mitwelt), among my "fellow men", there are also those who are not my direct consociates but "mere contemporaries" (Nebenmenschen). I know of them and their experiences not via direct empathic experience but only through inferences, typifications and idealizations. Moreover, unlike my consociates in my immediate surrounding or everyday life-world (my colleague at the desk facing mine, my friend sitting with me in the coffee shop, the child playing in front of me in the park, my neighbors, etc.), I can only interpret them, often through complex forms of social observation. Such observation will not be based on the perception and interpretation of gestures, facial and bodily expression, tonality of voice, etc., as in direct encounters but through complex mediation, for example by discursive, symbolic or technological means. Importantly, I cannot (easily) transform the observation of my contemporaries into direct interaction (ask them something, etc.) and "make the behavior and subjective experience of my contemporaries the [...] motives of my action" (Schütz 1932: 143). Finally, my social reality also includes those others who, unlike contemporaries, cannot ever become my direct consociates. They constitute the "world of my predecessors" (Vorwelt) and the "world of my successors" (Folgewelt). In neither can I ever become an actor or interactor. Concerning the world of my predecessors, though I am always and 
already deeply interlinked with them and stand in various social relations of generativity (see also Steinbock 1995), I am still confined as a historical observer. Concerning the future behaviour of my successors, on the other hand, I can only vaguely grasp and predict it by "supposing that [typical experiences] will be the same as those of my contemporaries and my predecessors" (ibid.; cf. Schütz \& Luckmann 1974: 98-138).

But this complex process of entertaining interpersonal relations has no clear-cut boundaries. There will always be an intermeshing or gradual transition from a more or less concrete, personal other in direct face-to-face encounters to a more or less "anonymous" proxy of a social type. Furthermore, typification for Schütz involves the recognition and grasping of an "objective web of meanings" (objektiver Sinnzusammenhang), practices or social facts in which subjects are always and already embedded. For instance, when greeting the postman who just handed you a letter, you become empathetically acquainted with both the nice smiling young man and the anonymous one whom you were eagerly awaiting this morning, but also with the surprisingly friendly representative of the state-owned service, which has recently been criticized for their bad-tempered, poorly paid employees (Schütz 1932: 227-90; Schutz \& Luckmann 1975: 98-139; cf. Zahavi 2010). Moreover, social typification is not only a means of understanding others' mental life but also of applying such understanding to concrete actions of concrete others, interpreting their motives, and thus predicting their behaviour and actions. Schütz gives the following "typical model" of such an analysis:

Applying the type to a concrete person, I can say, " $\mathrm{N}$ is a typical bureaucrat; therefore we may expect him to be visiting our office regularly." Or else, "N has just performed action a; a corresponds to ideal type A; $a$ ' is also characteristic of A; we may, therefore, expect $\mathrm{N}$ also to perform action a'.” (Schütz 1932: 228)

However, notice that this model in no way entails the corruption of freedom or some form of determinism, as if such a prediction would always be fully determinate and reliably indicate the actions and types in question (remember the issue of anti-collectivism, a position that Schütz readily subscribes to). Rather, such predictions are no more and no less than "interpretative schemes" and as such more or less "reliable", depending on the adequacy of the typification. The closer, the less idealized or the less anonymous the encounter with the other, the more information I receive in repeated direct empathic encounters or 'we-relationships' and the more spontaneous and free her actions become, to wit, relative to my idealized interpretative schemes. Thus, "the more anonymous my partner, the less direct and personal the relationship and the more conceptualized must my dealings with him be. And the more I conceptualize my partner, the less can I regard him as a free agent" (Schütz 1932: 219). 
In a similar vein, Gurwitsch maintains that others are always given in specific and at the same time typical, more or less familiar horizons of sense, as "bearers of roles", and in more or less specific social "situations" (Gurwitsch 1931: 111). As he puts it:

[others] do not surface "suddenly," "accidentally," or "by chance." [...] They immediately appear, instead, as existing concretely in the "co-included" situation. Not just any "human thing" emerges unexpectedly and sporadically [...]; it is rather the case that situations become visible in the horizons in which sellers, anonymous buyers, purveyors, employers, listeners, readers, masters, servants, etc., act out their roles. (Gurwitsch 1931: 97)

Moreover, Gurwitsch maintains, even basic facial expressions and gestures, such as shaking one's head or wrinkling one's brow, "are not in themselves unambiguous". Rather, the comprehension of such "expressive phenomena smoothly arises from knowledge about the situation in which I am with others, and fits into this knowledge as one of its moments" (Gurwitsch 1931: 113). Here, Gurwitsch explicitly departs from Scheler's idea of "a universal grammar" regulating the "elementary" relations between experience and its expression (Scheler 1926b: 11; cf. Husserl 1912-1916: 174-175).

Now, one of the strongest glues of intersubjective relations is communication. A central dimension of how persons relate to one another above and beyond empathic understanding, direct interaction or social typification that I have so far only touched upon is how we directly address each other. Paradigmatic examples of such acts of address are encouragements, requests, orders, indications, suggestions, or agreements. Furthermore, they include a distinctive class of acts, which, since Austin's groundbreaking work (1962), are known as speech acts (orders, requests, promises, etc.). Phenomenologists such as Husserl, Reinach (1913) and Stein $(1922,1924)$ have long before ordinary language philosophy dwelled on this issue under the heading of "social" or "socio-communicative acts" (soziale Akte, sozio-kommunikative Akte, soziale Stellungnabmen). Husserl also labels these "social I-Thou-acts and We-acts" (soziale Ich-Du-Akte und Wir-Akte; 1923-1924, 137). Reinach, who has most systematically addressed paradigmatic speech acts, calls them "other-directed acts" (fremdpersonale Akte).

Social acts have their phenomenological basis in empathy. However, it is important not to confuse the two social stances (Husserl 1905-1920: 98ff.). One significant difference concerns reciprocity. Empathy, as we have seen, can well be but is not necessarily reciprocal. This is quite unlike socio-communicative acts, which Husserl frequently characterizes precisely as reciprocal social relations (soziale Akte der sozialen Wechselbeziehung; 1950: 159; 1905-1920: 98ff.; 1921-1928: 166ff.). Touching on this, it is noteworthy that Husserl occasionally distinguishes 'reciprocal' from 'unilateral' empathy (wechselseitige and einseitige Einfüblung; 1921- 
1928: 133-135; 1905-1920: 98). Importantly-and here we have another difference from empathy-part and parcel of what makes such communicative acts social acts is that they have a specific normative content. In order for a social act to be successful, the addressor's intentions ought to be acknowledged by the addressee. Eventually, the addressor ought even to be assisted in the fulfilment of her intentions (cf. 1905-1920: 98; 1921-1928, 166f.). Similarly, for Reinach, the distinctive feature of such intentional acts is their specific communicative-cumnormative function in addressing somebody. Again, what makes them social is that they have an interpersonal feature built into their very intentional structure. Thus, they are only successfully issued if they are 'heard' or 'recognized' as such (vernommen) by their addressee. But if this is the case, they have the peculiar power to generate social and normative entities, such as, say, a commitment on the part of the issuer in the case of promises (cf. Mulligan 1987 and 2016).

Finally, socio-communicative acts do not necessarily presuppose linguistic forms of communication. In discussing such acts, Husserl points to something akin to a currently much discussed phenomenon, namely joint attention (Eilan et al. 2005; Seemann 2012; Tomasello 2014). Thus, somebody may 'guide' the attention of another by signalling, pointing or guiding in an even more implicit way, for instance by waving a hand. The other might then apperceive my action as expressing my intention to communicate something. Here, a shared background of understanding each other's communicative intentions constitutes the attentional link (Husserl 1921-1928: 167-168).

\subsection{Shared Life-World, Objectivity and the 'Transcendental We'}

But what is such a shared background of understanding, and how is it constituted? The notion of 'background' or 'common ground' is familiar to contemporary social ontologists. Searle, for example, defines "background practices" as a set of formally non-codified, but normatively constraining shared beliefs, attitudes and motivational states, which enable interpersonal (linguistic) understanding. It also exercises a "background power" on the behaviour of individuals and determines the appropriateness conditions of their intentional states (cf., e.g., Searle 2010, 155-160; see also 1995, chap. 6). But, though Searle explores in some detail how the background works and enables individual and collective intentionality, like most philosophers using this rather vague notion, he is silent on how exactly this background is constituted.

Here, phenomenologists can build on the notion of the everyday lifeworld, which is especially well worked out in Husserl (1954; 1916-1937) and Schütz (Schütz \& Luckmann 1974). To be sure, the concept of the life-world is notoriously complex. Definitions for example in Husserl's Crisis-text (1954) oscil- 
late between the pre-theoretical, non-idealized or non-mathematized world of intuitive, taken-for-granted experience, presupposed by any science, and the world in which scientific theories, sociocultural facts and practical achievements of previous generations have already 'sedimented' themselves and become habitualized and part and parcel of precisely everyday experience. Husserl also characterizes it as the ground (Boden) upon which every scientific and cultural endeavor is 'founded' and from which they gain their 'sense' and intersubjective validation. Furthermore, a sociologically important conception of the life-world is what Husserl calls the "home-world" (Heimwelt), defined in relation to the "alienworld" (Fremdivelt) and delineated by the bound of individuals' "habitual style" of experiencing (Gewohnheitssti), or the conceptions of the "familiar", the "typical" and the "normal" for one's given community (e.g. Husserl 1916-1937: 8-9, 106, 208; cf. Steinbock 1995).

But however exactly one cashes out the notion of the life-world, what is crucial is that it is not only intersubjectively shared but also intersubjectively constituted in the first place. Husserl emphasizes that notwithstanding the relativity of the different socio-historically and culturally stratified life-worlds there is a (transcendental) sense in which there is an "intersubjectively identical lifeworld-for-all" (Husserl 1954: 175f.). The subject-correlate of this universally shared life-world is accordingly not a set of individual subjects nor specific communities but rather the "transcendental We" (Husserl 1950, 137). The world, for Husserl, is not only my and your and their world but all stratification of the world is just a modalization of the sense in which the world is at bottom our shared world:

$[\mathrm{W}]$, in living together, have the world pre-given in this 'together,' as the world valid as existing for us and to which we, together, belong, the world as world for all, pre-given with this $[\ldots]$ meaning. $[\ldots]$ we also function together, in the manifold ways of considering, together, objects pre-given to us in common, thinking together, valuing, planning, acting together. Here we find also that particular thematic alteration in which the we-subjectivity [is] constantly functioning. (Husserl 1954: 109)

Moreover, the transcendental or "general" We (Husserl 1954: 175f.) has its own constitutive function, which goes far beyond the establishment of interpersonal relations. It is responsible for the constitution of the very self-identity of objects across their potential givenness to a multiplicity of different perspectives and eventually of an objective world or objectivity as such. ${ }^{7}$ This "constitutive inter-

\footnotetext{
${ }^{7}$ Crowell $(2012,573)$ puts this point succinctly: "For Husserl, constitution of the Other does not merely add an item to the world; it informs the sense of everything I experience. [...] Though Husserl does not argue the point here, his demonstration that experience of an 'objective world common to us all' depends on the availability of the Other as a constituted sense entails that the Other is a condition for any intentional content at all, any experience of something as something. This is because the Other (in a way that, as we shall see, Husserl does not adequately clarify)
} 
subjectivity" (Zahavi 2001, 115), then, is a kind of transcendental primitive in the ontology of not just social reality but experiential reality as such. Notice that, however fundamental this layer of intersubjectivity might be, it is nothing above and beyond individual subjects. There is, to be sure, no other intersubjectivity than the one constituted precisely by individual subjects. However, insofar as individuals are members of the transcendental community and inhabitants of the social lifeworld, their experiences are such that they are impregnated, as it were, by a 'we-mode'. And it is precisely in this sense that Husserl pluralizes Descartes' solipsistic 'ego cogito' and Leibniz' 'monads' and speaks of the "communalization of monads" (Vergemeinschaftung der Monaden) (1950: 149-156) and "nos cogitamus" (1923-1924: 316). ${ }^{8}$ What we have here is a sharing of a first-person plural perspective, built into not just the apperception of the lifeworld as common to all, but also into every individual perception of any given object. ${ }^{9}$ But, surely, the transcendental We is not the only form of community in social reality that phenomenologists have explored.

\section{The Phenomenology of Community}

With few notable exceptions such as Heidegger, most phenomenologists hold that the social dyad or some form of face-to-face interpersonal relations lies at the bottom of social reality. ${ }^{10}$ However, it is crucial not to misunderstand this claim: We do not find a single classical phenomenologist who would infer from this that all there is to social reality are interpersonal relations, or that more complex and mediated social formations were in some sense or another (ontologically, phenomenologically or explanatorily) reducible to such relations. Quite the contrary, interpersonal and collective forms of being-together represent the two ends of the social spectrum and the most important explananda of a full-blown analysis of social reality. There are not many other traditions in social thought that have investigated in more detail both these forms and, even if not always quite explicit-

provides a necessary condition for any genuine re-identification of things in my own experience. Only if re-identification is possible can I experience something as something."

${ }^{8}$ See Carr 1973, 30: "The establishment of the we in common perception is the simplest form of what Husserl calls the Vergemeinschaftung der Monaden: when two subjects confront one another and stand in relation to the same objects they form, to that extent, a rudimentary community that can itself be considered as performing an act (cogitamus) through 'its' diverse (and in this case simultaneous) presentations." Cf. also Carr 1986 and, critically, Chelstrom 2013, chap. 3; cf. also Schmid 2009, Zahavi 2014, and Miettinen 2014.

${ }^{9}$ Cf. also Husserl 1921-1928: 74, 94, 99, 173, 196ff.; 1928-1935, 331ff.; 1916-1937, 260ff., 385ff., 491; 1929-1934, 178ff., 369ff., 430ff. See more on this issue also in Szanto $2016 \mathrm{a}$.

10 See in this connection Sartre's criticism of Heidegger's prioritizing Dasein's Being-with-Others in comparison to her Being-for-Others (esp. 1943, 247-252). 
ly, their complex interrelation. ${ }^{11}$ Moreover, a number of phenomenologists have engaged in painstakingly thorough attempts to distinguish different types of social formations and to elucidate their interrelations. These formations range from anonymous, unorganized or temporary gatherings and crowd formations to instrumental associations or societies (Verband, Gesellschaft), complex, collaborative and highly cohesive forms of communities (Gemeinschaft) and finally group minds or group persons. Such a project was very much familiar to the sociological contemporaries of early phenomenologists, from whom many in fact drew their inspiration. From the grandfather of German sociology, Ferdinand Tönnies (1935), to less well-known but influential figures such as the unduly forgotten Theodor Litt (1919) or Alfred Vierkandt (1928), all have embarked on systematic socio-ontological taxonomies, a project that has become rather unfashionable in recent social philosophy.

Moreover, we find a number of highly sophisticated accounts of the possibility and nature of collective intentionality, shared emotions, group personhood and group agency. They are remarkably coherent with and often improve upon some of the best available accounts in contemporary social ontology, represented for example by philosophers such as Gilbert (1989), Bratman (2014), Searle (1995, 2010), Tuomela (2013) or List and Pettit (2011). Thus, it should come as little surprise that the very term 'social ontology' was first coined by Husserl more than a hundred years ago (Husserl 1973, 102; cf. Salice 2013; Caminada 2011; Szanto 2016a).

Finally, phenomenologists such as Scheler, Stein and Walther hold that the stratification of social communities is in large part determined by differences in how ways of being-together are phenomenologically experienced by individuals from a first-person plural or 'we'-perspective. Rather than due to exogenous or instrumental factors such as rules or norms, let alone statistical regularities, these stratifications are due to how communities are affectively integrated and how the individuals' experiences are "colored" by communal experiences (Stein 1922). ${ }^{12}$

\subsection{Types and Forms of Sociality}

Among the accounts that offer the most fine-grained taxonomy of social formations ranks Scheler's treatment in his Formalism book (1926b). Scheler begins

\footnotetext{
11 In particular Scheler (1926a, 1926b), Stein (1922), the unduly forgotten Otaka (1932), Schmalenbach (1922), and Hildebrand (1930), but also Husserl (cf. Szanto 2016), Gurwitsch (1931), and the later Sartre (1960).

12 For useful concise explorations of the different social formations and the role of weexperiences, empathy and shared emotions therein, esp. concerning Scheler, Walther and Gurwitsch, see León \& Zahavi 2016; Zahavi \& Salice forthcoming; Chelstrom 2016; Zahavi forthcoming; Szanto 2015, and Szanto forthcoming.
} 
with distinguishing four distinct types of "social unities" (soziale Einheiten). Importantly, Scheler's project is not just an ontological but also an axiological, or value-theoretic, project, and accordingly has a normative impetus. Thus, he distinguishes "kinds of being with one another" according to the "kind and rank of values" constituting norms of social relations between members (Scheler 1926b, 515ff; 1911-21, 266; 1960, 437). Furthermore, for the sociologist of knowledge Scheler, various epistemic forms of thinking, knowledge and representation also correspond to these social unities (Scheler 1924, 33f.).

(i.) First then we have the "mass" or "horde" (Masse, Herde). This social formation was famously analysed by Le Bon (1895) as a more or less temporary and-in sharp contrast to the by-now proverbial 'wisdom of the crowd'essentially irrational collective. Similarly, for Scheler, it is characterized by emotional "contagion and involuntary imitation devoid of understanding" (1926a, 515). In emotional contagion, someone is causally affected by another's affective state, quite literally 'taking over' another's emotions or becoming immersed in a given affective atmosphere. Without really being affectively 'fused' (as in emotional identification, see below), individuals are 'swept into' one another's situation and hence lose the sense of a boundary between one's own and another's affective life. Typically they will not even be aware of the psychodynamics at play, which makes the affective situation prone to tipping into dangerous crowd dynamics (see more, sec. 3.3). Moreover, instead of founding or facilitating empathy, sympathy or solidarity, the blurring of self-/other-boundaries in such emotionally contagious crowd dynamics rather hinders these other-directed stances.

(ii.) Secondly, we have Scheler's version of Tönnies' (1935) concept of 'community', namely the "life-community" (Lebensgemeinschaft), such as families or tribes. Two chief characteristics of this highly cohesive and robust form of sociality stand out: a specific form of "co-experiencing" (Miteinandererleben) others' mental and affective states and a specific principle of solidarity, the so-called "representable (vertretbare) solidarity". The distinctive feature of communal coexperiencing is that the phenomenal and intentional content of a set of individuals' experiences is "truly identical" (1926a, 516). In communal co-experiencing, then, one is neither empathizing (Scheler's Nachfüblen) with another, nor simply having experiences 'in tandem with' others. Rather, there is no proper distinction between self and other or between the subjects of experience. On the affective level, this form of communal co-experiencing corresponds to the emotional fusion, e.g. in ritualistic worship, that Scheler (1926b) characterizes as "emotional identification" (Einsfüblung). ${ }^{13}$ Here, an individual's self-experience is deeply affected by her membership in such "pure" communities. One is aware of oneself only

${ }^{13}$ Notice, however, that not all forms of 'co-experiencing' or 'co-feeling' have this fusional or token-identity structure; see more below, sec. 3.3. 
as the subject of co-experiencing together with others. Thus, the life-community "arise[s] on the basis of the fact that, although the experiences of individuals are given as such, they vary with regard to their course and content in complete dependency on the variations of communal experiences" (1926b, 516). But this experiential and affective dependence also affects the sense and normative structure of solidarity at stake. Individuals are collectively responsible for the volitions and actions of the community, and indeed their self-responsibility comes only after collective responsibility (1926b, 488, 515ff.; 1960, 437).

(iii.) In sharp contrast to the life-community stands society (Gesellschaft). This is an instrumental association of "mature", "self-conscious" individuals, or autonomous persons (Scheler 1926b, 518), formed in the pursuit of some shared aim. It roughly equals Tönnies' (1935) and Weber's (1922) familiar conception of society where individuals are bound together to realize possibly purely egoistic interests and values.

(iv.) Lastly we have what Scheler calls "the unity of independent, spiritual (geistig), and individual single persons 'in' an independent, spiritual and communal person (Gesamtperson)" (1926b, 522). It is important not to misunderstand the personalist connotations here: Communal persons $(\mathrm{CP})$ are not supra-individuals or some free-floating macro entities above and beyond individuals. Whether or not a social formation is a CP is not a matter of scope, and there is no one ultimate, maximum-sized or all-encompassing CP. Though CP are "not a synthesis" of societies and life-communities, they are nevertheless considered to be a higher order socio-ontological reality (böhere Gesamtrealität) founded upon societies and communities $(1916,336)$. Thus, they exhibit the key features of both social formations. On the one hand, members of a CP are the independent and autonomous individual persons of societies; on the other hand, they are bound together by the strong principle of solidarity and sense of "real communal unity" (Gesamteinheit) of life-communities (1926b, 527). But individuals' self-responsibility is not corrupted in a collectivist fashion by their membership in CP, as may be the case in life-communities. Rather, the solidarity at stake is a "system of solidarity of autonomous, self- and co-responsible (mitverantwortlich) individuals" or "the personal-solidary association of non-representable (unvertretbar) individuals" (1926b, 33, 45). Moreover, CP are not just characterized by a specific sense of coresponsibility and solidarity among their members. They form a complex but highly cohesive social integration of the very experiences, volitions and actions of individuals. Essentially, CP are not just abstract groupings but "experienced realities" (1926b, 511f.). They are constituted by and experienced in those specific intentional acts that Scheler calls "mutual co-experiencing" or "co-living" (Miteinandererleben, Miteinanderleben). Thus, what makes communal persons personal is that they bear the intrinsic value of persons and exhibit a certain first-personal 
character of experiencing: they are "act-centres of experiencing within the coexperiencing of persons" (1926b, 512). Now, co-experiencing something with others for Scheler means that a subject is experiencing something and, at the same time, experiencing herself as a member of a community for which, and for whose members, she bears solidarity and co-responsibility. Hence, the experiential and normative properties of social integration of experiences are, at the level of CP, inseparably and constitutively tied together. Scheler offers a bewildering taxonomy of CP, but the examples he typically mentions are the state (as distinct from both people and nation), so-called "cultural regions" and "cultural nations" (Kulturkereis/-nation) and, above all, in its axiologically "highest" and "purest form", the church, incorporating the universal "community of love" in which all individual persons partake (1926b, 531ff.) (see more in Krebs 2015; Szanto 2016b).

In a Marxist-cum-Hegelian reversal of Scheler's conservative 'communitarianism' (without explicit reference to Scheler, to be sure), Sartre offers an alternative analysis of different social beings in his today little-known two-volume work, Critique of Dialectical Reason. Sartre views the formation, fragmentation, dissolution or maintenance of socialities as a constant movement of a dialectical progression of ossification, annihilation and determination of individual and common praxis. This movement reflects the interpenetration of extraneous material structures and their exigencies, the function of "third-parties", such as antagonistic other groups, and those factors that are immanent to the self-determining tendencies of a collective. Sartre's aim is to provide a novel phenomenological and materialist analysis of the concept of class (the working class, the nobility, the bourgeoisie, the serfs, etc.). Sartre's analysis may be somewhat outdated in doctrine and oftentimes idiosyncratic to the point of incomprehensibility, and he has already been criticized by famous contemporaries such as Merleau-Ponty as an "ultraBolshevist" (1955). At the same time, his analysis provides a blueprint for an intriguing contribution to the notion of collective agency, which has recently been much debated in analytic philosophy of action. To see why, let me here explain the difference between three of the many social ensembles that Sartre explores (others include in particular "organizations" and "institutions" (1960: 445-663)).

Sartre begins his analysis of social dialectics with the so-called "seriality", i.e., a set of individuals reciprocally negating and at the same time determining each other in their "alterity". Using this notion, Sartre discusses so-called "gatherings", collections of individuals in seriality, who, in the face of contingent external factors, center their individual practical projects around a "common", though not shared, "interest" and hence constitute a "serial unity" (1960: 261-265). Sartre's example is a random collection of a handful of commuters who have different sociocultural backgrounds and just happen to wait for a bus at the same stop. They queue up to buy tickets, knowing that seats are limited and they might have 
to wait for the next bus. They have individual and even antagonistic interests and stand in relations of "reciprocal isolation". Gatherings don't have their own rationality or goal, i.e. there is no "entelechy". Yet, the sheer fact that "they are grouped around the same bus stop" and have a "common interest" "unites them from the outside" and provides them with a certain, however fleeting and practically "inert" or non-self-determined, socio-ontological structure (1960: 258). Though the individuals are typically inattentive and unaware of this structurethey don't have a unitary "identity" of being 'those who wait for the bus'-their commonality may become "manifest", and they may define themselves "in relation to their common interest" (1960: 260). Suppose, for example, that loudspeakers announce that due to a drivers' strike there will be no bus service for the day and therewith trigger such awareness.

Now, this is exactly what happens in the so-called "fused group" (1960: 345-404), which is still an "unstructured" or "amorphous" (1960: 357) ensemble, and eventually in the next dialectical step, in the so-called "statutory" or "surviving group" (1960: 404-445). What emerges there is individuals' "group consciousness", an awareness of their "being-in-the-group" (1960: 414). Thus, under certain material, historical or simply situational circumstances, and particularly in the face of exigencies, danger or scarcity, "passive" or "practico-inert" social ensembles determine some common goal and constitute themselves as active groups, eventually resulting in a "revolutionary group praxis". Such active groups, in turn, are under constant threat of disintegration and of becoming "ossified", "institutional" collectives (1960: 347-348). Notice that group consciousness, like Scheler's communal person, is not some emergent group mind, but individuals' "recognition" of their "own action in the common action". Sartre emphasizes the active and practical nature of the integration at stake: "my integration becomes a task to be done"(1960: 408). The paradigm case, eliciting such ever-tighter social integration, for Sartre, are spontaneous revolutionary movements under external pressure (e.g., danger of elimination in the face of an oppressor or an army), which he illustrates by an analysis of the storming of the Bastille in the French Revolution of 1789.

For Sartre, common need, common praxis and common objectives determine common agency, but they are not sufficient for the constitution of more robust groups. The group must constitute itself as an agent that frames the common goal as something that each and every individual member identifies with and eventually enacts in common praxis: a group must "mak[e] itself into a community by feeling individual need as common need and by projecting itself in the internal unification of a common integration, towards objectives which it produces as common" (1960: 350). This constitution involves the familiar socially transformative processes: at the bottom, "imitation" of others' behaviour and "conta- 
gious" crowd behaviour (1960: 353-354), eventually enacting practices such as constituting hierarchies and alliances - specifically in opposition to the "third party", or the Other of the group (1960: 362-373) —and establishing majority voting, lawmaking, symbolic representation, and collective agreements.

\subsection{Collective Intentionality}

Among the social formations phenomenologists distinguish we find group agents, acting upon collective agreements and pursuing common goals. In the jargon of contemporary analytic philosophy, group agents act upon collective intentionality. However controversial the idea might still be that groups can be conceived of as genuine agents of their own and possibly "with a mind of their own" (Pettit 2003), most contemporary authors agree that collective intentionality cannot be reduced to a mere summation or aggregation of individual intentions. To use Sartre's example, the fact that you and I happen to intend to ride the same bus won't make our intentions shared. Mere coordination of our actions or mutual knowledge of one another's intentions won't suffice either. Over the past three decades a number of proposals have been put forth as to how to account for the fact that two or more subjects can jointly intend to do something, to wit, given that intentions are traditionally conceived as paradigms of individual mental states (Schweikard \& Schmid 2013; Tollefsen 2015). And in the last couple of years, a growing number of scholars have mined classical phenomenology, demonstrating that there are ingenious proposals already developed by Husserl, Heidegger, Scheler, Ingarden, Gurwitsch, Stein, Walther and Schmalenbach. ${ }^{14}$

Husserl offers one of the most compelling accounts of collective intentionality avant-la-lettre. In the broadest of brushstrokes (see in detail Szanto 2016a), for Husserl, collectivity in collective intentions is constituted by the appropriate integration of the intentional, goal-directed, normative, volitional and practical properties of the mental life of always and already socialized and communalized individuals. More specifically, the integration is not so much brought about through mere collective agreement (as, e.g., for Tuomela 2009); nor is it effected by the appropriate "interlocking" of individual "subplans" in attaining a shared goal (as for Bratman 2014), or the "joint commitment" to do something together and form a "plural subject" enacting this joint commitment (as for Gilbert 1989), just to mention three influential contemporary accounts-though Husserl's account integrates elements of all these dimensions. Rather, the jointness is built into the very intentional act through which one subject functionally enters into the intentional content of another subject as joint 'means' to attain a shared goal. The

14 See, e.g., Schmid 2005; 2009; Caminada 2014, 2015, 2016; Burns 2015; and the contributions in Szanto \& Moran 2015; Szanto \& Moran 2016; and Salice \& Schmid 2016. 
shared goal, the object correlate of the respective intentions, is thus 'represented', as one might phrase it in Searle's terms (1990; 1995), as the same intentional content in both intentions. Hence, the result is a genuinely 'we-mode' intention. Here is how Husserl, in remarkably contemporary fashion, puts it:

A community of will, consent (Einverständnis), may then also be mutual, resulting in a mutual agreement (wechselseitige Vereinbarung). I satisfy your desire if you satisfy mine (...). Furthermore: We both want something to happen, we 'jointly' ('gemeinsam) take a decision, I do my respective part, you do yours, etc. $S_{1}$ and $S_{2}$ want $G$, but not each of them separately, for their own sake, but $S_{1}$ wants $G$ as something that is equally wanted by $S_{2}$, the will of $S_{2}$ is part of what is willed by $S_{1}$ (der Wille des $\mathrm{S}_{2}$ gehört mit zum Gewollten des $\mathrm{S}_{1}$ ) and conversely. The fact that $\mathrm{S}_{1}$ realizes $\mathrm{D}_{1}$ and $\mathrm{S}_{2} \mathrm{D}_{2}$ is, in turn, comprised in the volitions of both, comprised as 'means' (in a broader sense), or, as part of what belongs to the realization (als zur Realisierung gebörig), and, originally, to the intention (Absicht). (Husserl 1921-1928, 170; own transl. $)^{15}$

If the thus reached intentional integration is robust enough, what is thus constituted is a group agent or, as Husserl calls it, a "common mind" (Gemeingeist) or "higher order person" (Persönlichkeit böherer Stufe), a notion reminiscent of Scheler's common person (1921-1928: 165-204). This typically happens through the "sedimentation" of collective intentionality in the experiences and attitudes of the individuals involved via habits, tradition, or culture (Husserl 1908-1937: 39ff., 62ff.; 1921-1928: 222-232; 1916-1937: 387-389). Husserl also suggests that contracts and explicit agreements may become sedimented and acquire "habitualized validity" (habituelle Geltung), normatively binding members to fulfill the commitment (e.g., 1929-1934: 334.). And the strongest form of such bonds without explicit prior agreement is constituted through the "habitualized identification" of the affective and volitional dimension in "love communities" (habituelle Identifikation der Gemüts- und Willenssubjektivität) (Husserl 1923: 209). We find another wellworked out account of such "habitual unification" (habituelle Einigung) of the mental and affective lives of individuals in Walther (1923; see Szanto forthcoming).

\subsection{Shared Emotions}

Social relations are almost always affectively charged. Sociality has not only its ontology and epistemology but also its often richly differentiated phenomenology. Other individuals and groups matter or concern us-some more, some less. As indicated, for phenomenologists, empathy does not amount to intentional or emotional sharing. However, social cognition is not just cognition but is typically embedded

\footnotetext{
15 Similar descriptions can be found in a number of places in Husserl's research manuscripts; see,
} e.g., 1916-1937: 389, or 1923: 209. 
in some affective interaction between agents. Moreover, one of the distinctive features of the phenomenological accounts is that they view collective intentionality not just as a matter of integration and habitualization of cognitive, conative or volitional states (intentions, desires, representations of action plans, etc.), or as a matter of coordination, team reasoning or rational deliberation, but as a matter of experiential and indeed affective integration. When agents plan, intend or act together, they typically do so on the basis of what phenomenologists call a "feeling-of-belonging together" (Gefübl der Zusammengehörigkeit, Walther 1923) or "communal experience" (Gemeinschaftserlebnis; Stein 1922), or, as Scheler coins it, a "feeling-in-common" (Miteinanderfüblen; Scheler 1926a). Finally, as we have seen, it is in large part precisely the different types and mechanisms of affective integration that do the work in the stratification of social communities.

But how is it possible to literally share affective states or emotions? Social psychologists, sociologists of emotions and philosophers have recently offered a number of answers ${ }^{16}$, but many accounts suffer from serious conceptual ambiguities when it comes to distinguishing emotional sharing from cogent but distinct phenomena, such as emotional contagion, intragroup affective dynamics, etc. In contrast, the work of classical phenomenologists such as Scheler (1926a), Stein $(1917,1922)$ or Walther (1923) contains precise conceptual schema to distinguish them. As a striking example, consider Scheler's (1926a) fine-grained distinctions between empathy (Nachfüblen), emotional identification (Einsfüblung), emotional contagion (Gefüblsansteckung; Scheler 1926a, cf. also Stein 1917, 1922; Walther 1923), 'feeling-with', or 'sympathy' (Mitfüblen, Sympathie), and, finally, proper emotional sharing, or feeling-in-common (Miteinanderfühlen). Moreover, phenomenological accounts of emotions emphasize their intentional, cognitive and evaluative as well as bodily and qualitative components (Kolnai 1927, 1998; Sartre 1943; Vendrell Ferran 2016). ${ }^{17}$

To get a grip on what is and, in particular, what is not at stake in the phenomenology of emotional sharing, it is helpful to distinguish four dimensions of the sociality of emotions. The phenomenology of emotions of authors such as Scheler, Stein and Walther is primarily, though certainly not exclusively, concerned with the fourth dimension. Roughly, the first three dimensions in which social relations and facts come into play in the affective life of individuals and groups are: (i) the interpersonal (e.g., I get sad if my partner is sad); (ii) the group and

${ }^{16}$ For sociology, see, e.g., Rimé 2009; Collins 2004; Stets \& Turner 2007; Rivera \& Páez 2007; for psychology, e.g., Parkinson et al. 2005; Smith et al. 2007; Sullivan 2015. See also Ahmed 2004. For the most convincing philosophical accounts within the analytic tradition, see Salmela 2014 and Salmela \& Nagatsu 2016a. See also Gilbert 2002, 2014. For an excellent collection of essays, see von Scheve \& Salmela 2014.

${ }^{17}$ For conceptually rich contemporary phenomenological proposals, see Schmid 2009, 2014; Zahavi 2015; Guerrero 2016; Krebs 2016; Krueger 2016; I have explored this topic in more detail in Szanto 2015; Szanto forthcoming, and León, Szanto \& Zahavi forthcoming. 
intergroup (I am sad if my team loses); and (iii) the sociocultural dimension (I feel shame in the face of violating certain social norms, and I only feel this because I have learned to appropriately respond to certain situations with certain emotions) (cf. Parkinson et al. 2007, 11). (iv) Regarding the fourth dimension, shared emotions proper, and the sense in which it is marked off from the other three, consider the locus classicus for all subsequent phenomenological accounts, a passage from Scheler's Sympathy book:

The father and the mother stand beside the dead body of a beloved child. They feel in common the 'same' ('dasselbe') sorrow, the 'same' anguish. It is not that A feels this sorrow and B feels it also, and moreover that they both know they are feeling it. No, it is a feeling-in-common. A's sorrow is in no way 'objectual' (gegenständlich) for B here, as it is, e.g., for their friend C, who joins them, and commiserates 'with them' or 'upon their sorrow'. On the contrary, they feel it together, in the sense of a feeling- and experiencing-in-common, not only the self-same value-situation but also having the same emotional agility (emotionale Regsamkeit) toward [the situation]. The sorrow, as value-content, and the grief, as characterizing the functional relation thereto, are here one and identical. (Scheler 1926a, 24)

We can reconstruct Scheler's example by distinguishing three dimensions of how the typically other-directed emotion of grief is embedded in a complex of further social relations:

(i) I (personally) grieve for our child.

(ii) I as a parent or family member grieve for our child.

(iii) We as parents grieve for our child.

Notice that in (i) and (ii)—although the grieving subject is an individual-either the intentional object of the emotion or the specific mode in which the emotion is experienced is shared with others. In (i) the sharedness is built into the shared intentional object ('our child'); in (ii) the shared object (the grief directed at our son) is experienced as a member of a specific social grouping, and comes about by means of identifying with those others or groupings (my partner, family, etc.). But how do phenomenologists account for (iii), where the subject seems to be a collective and is typically expressed in the first person plural? That is, how can individuals share an emotion in the sense of (iii)?

The answer is provided if we consider the following three requirements expressed, even if not explicitly, in most phenomenological accounts of emotional sharing:

(1) Intentionality and (Mutual) Awareness Requirement

(2) Integration Requirement

(3) Plurality and Self-/Other-Differentiation Requirement 
The first requirement is meant to contrast shared emotions with emotional contagion. As we have seen, in emotional contagion, the affective state that one experiences 'in tandem with' others is not properly speaking shared, since it is typically characterized by the lack of a common intentional focus. Imagine that someone enters a bar and is affected by the cheerful or aggressive atmosphere without perhaps even realizing that this atmosphere is caused by the people having just finished watching an exciting sports event on an already turned-off screen (cf. Scheler 1926a). In typical cases, one will not even intentionally enter into the situation of such affective 'commonality'. Contrast this with a situation in which someone decides to partake in a public viewing event precisely for the sake of sharing the excitement of watching the game together with others. In emotional contagion there might be only 'affective mimicry', which is non-intentional, and there is typically no mutual awareness of sharing any affective states. I might be aware that I am sharing the excitement with others. But it might still be that no one else realizes that I am present or undergoing the same or similar emotion. That is not to say that no properly shared emotional focus may eventually come into relief, and possibly also a mutual awareness of this. On the contrary, contemporary authors rightly suggest (Hatfield et al. 2014; Salmela \& Nagatsu 2016b) that emotional contagion often lies genetically at the bottom of proper emotional sharing-without, to be sure, presupposing that it is a necessary or sufficient constituent of the latter. This is ultimately an empirical claim that many phenomenologists including Scheler, Stein, Walther, and in some sense also Sartre would have no problem subscribing to.

Concerning the second requirement, bluntly put, the claim is that we have no proper emotional sharing without accounting for a robust sense in which individuals' emotions are deeply "unified" (Walther 1923) or integrated, constituting a genuinely novel emotion that results from precisely this integration (which, to be sure, is still felt by individuals). This will, minimally, entail a coherence of the expression and regulation of the emotions across members; shared patterns of appraisals and concern or a joint focus of import (' $\mathrm{I}$ care about $\mathrm{x}$ because it is

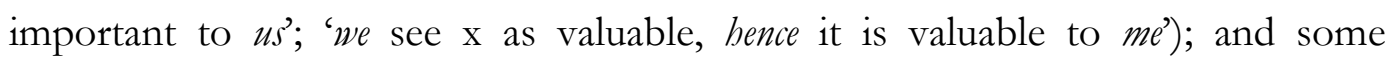
reciprocal modulation of the individuals' affective experience itself (that I share the grief with you influences the very way I feel the emotion). Some contemporary authors, who are in fact inspired by classical phenomenological accounts, have gone too far in their attempt to safeguard this requirement. They try to account for it in terms of a "phenomenal fusion" or strict "token-identity" of the respective emotional episodes (Schmid 2009, 2014; Krueger 2016; cf., critically, Szanto forthcoming, and León, Szanto, Zahavi forthcoming). However, just as there can be no proper sharing without something that is common and rightly integrated, there is just as little room and no need for sharing if there is not a plurality of 
individuals who actually engage in sharing. To put it in a formula: no sharing if there is nothing common to be shared, but no sharing either if there is nobody (other than oneself) to share with.

This, then, is the reason why the third requirement is needed. As should be clear from its double characterization ('plurality' and 'self-/otherdifferentiation'), it not only states the just mentioned and rather obvious fact that there is no sharing without two or more individuals who actually engage in sharing (hence: plurality) but also states that those individuals - their robust integration notwithstanding — actually differ and have a clear awareness and understanding of precisely not being fused, let alone identical, in their affective lives. Rather, in various aspects, they exhibit some experiential variations (e.g., they need not grieve with the very same intensity) and differences vis-à-vis one another (hence: self-/other-differentiation).

\section{Conclusion and Future Directions}

Phenomenologists offer uniquely rich descriptions of social reality. They have influenced sociological thought for more than a hundred years. Above and beyond the already mentioned authors, sociologists such as Bourdieu or Garfinkel have taken up phenomenological insights and applied them to concrete sociological research. But phenomenology's contribution to sociology could arguably be taken further. For example, a fruitful avenue for future research would be to draw on phenomenological conceptions of social typification, sedimentation and habitualization of intentional and affective states and their role in what the sociologist of emotions Eva Illouz calls "emotional habitus", "emotional cultures" or "emotional capital" (Illouz 2007; cf. also Ahmed 2004). Furthermore, the social dimension of embodiment discussed in extenso in Husserl or Merleau-Ponty as well as contemporary phenomenological accounts of the body as a sociocultural artifact (e.g. Dolezal 2015) or affective 'intercorporeality' (e.g. Fuchs forthcoming) have still not been sufficiently recognized in the 'corporeal' or 'body turn' in sociology (Turner 2008; Schilling 2011).

To be sure, phenomenological approaches to intersubjectivity and phenomenological sociology, be it in a Husserlian, Schutzian or other spirit, have not been spared from criticism from various camps. Critical and post-critical theorists such as Habermas or Apel or sociologists such as Luhmann have launched sustained objections against its alleged triad of transcendentalism, subjectivism and solipsism (cf. Schmid 2000; Zahavi 2001). Many of the above sketched tenets of classical phenomenology have also been attacked from within the movement, notably by Heidegger (cf. Theunissen 1965; Koo 2016; Schmid 2005; Overgaard \& Zahavi 2009). I hope to have shown, however, why the phenomenological 
approach should not be seen as a perhaps historically interesting but ultimately outdated theory but rather still deserves to be taken seriously by contemporary social theory. First, it provides a complex answer to the still unresolved key socioontological challenge of how to accommodate a holistic account of individuals within an anti-singularist picture of social reality, to wit, without succumbing to either normatively threatening collectivism or a metaphysically untenable, radical social constructivism. Secondly, phenomenologists provide a fine-grained taxonomy of social formations that pays due attention to the complex stratification of social relations and allows us to account for the fact that different means of social integration (intentional, face-to-face, habitualized, affective, etc.) constitute different types of social groupings. Finally, they provide a multi-layered conceptual framework that distinguishes forms of intentional and affective sharing that have typically been either ignored or confused by alternative theories, and that is suitable for analyzing the cognitive, affective, normative and above all experiential dimension of being-together. Consequently, phenomenology can be seen as one the few, if not only, theoretical approaches to social reality that represents a comprehensive account of the relation between first-personal, second- or interpersonal and first-person plural experiences. Thus, a running thread throughout phenomenological accounts seems to be the idea that the socialization of individuals and their forming, maintaining and enacting social groupings, or their communalization, are just two sides of the same coin. If we recognize phenomenology's key insight that individuals are ab ovo socialized and communalized, or that they are subjects who always already stand in complex social relations to one another, then there is hardly any mystery in how individuals can act, intend or indeed feel together.

\section{Funding Acknowledgment}

Work on this paper was generously supported by my European Union (EU) Horizon2020 Marie Skłodowska-Curie Individual Fellowships research project SHARE (655067): Shared Emotions, Group Membership, and Empathy. 


\section{References}

Ahmed, Sara (2004). The Cultural Politics of Emotion. London: Routledge.

Barber, Michael D. (2004). The Participating Citizen. A Biography of Alfred Schuts, Albany: State University of New York Press.

Baron-Cohen, Simon (1995). Mindblindness: An Essay on Autism and Theory of Mind. Cambridge, MA, London: MIT Press.

Baron-Cohen, Simon, Michael Lombardo, \& Helen Tager-Flusberg. (Eds.) (2013). Understanding Other Minds. Perspectives from Developmental Social Neuroscience. Oxford: Oxford University Press.

Berger, Peter L., and Luckmann (1966). The Social Construction of Reality: A Treatise in the Sociology of Knowledge. New York: Anchor.

Bernstein, Richard J. (1978). The restructuring of social and political theory. Philadelphia: University of Pennsylvania Press.

Butterfill, Stephen (2013). Interacting Mindreaders. Philosophical Studies 165 (3), 841-863.

Burns, Tim (2015). On Being a 'We': Edith Stein's Contribution to the Intentionalism Debate. Human Studies 38(4), 529-547.

Bratman, Michael (2014). Shared Agency: A Planning Theory of Acting Together. Oxford: Oxford University Press.

Caminada, Emanuele (2011). Husserls intentionale Soziologie. In Die Aktualität Husserls ed. V. Mayer, C. Erhard \& M. Scherini (Eds.). Freiburg, München: Alber, 56-85.

Caminada, Emanuele. (2014). Joining the Background: Habitual Sentiments Behind WeIntentionality. In Institutions, Emotions, and Group Agents. Contributions to Social Ontology, ed. Anita Konzelmann Ziv, and Hans Bernhard Schmid, 195-212. Dordrecht: Springer.

Caminada, Emanuele (2015). Edith Stein's Account of Communal Mind and its Limits: A Phenomenological Reading. Human Studies 38(4), 549-566.

Caminada, Emanuele (2016). Husserl on Groupings. Social Ontology and Phenomenology of We-Intentionality. In The Phenomenology of Sociality: Discovering the 'We'. Ed. T. Szanto, D. Moran, 281-295. London, New York: Routledge.

Carr, David (1986). Cogitamus Ergo Sumus: The Intentionality of the First-Person Plural. The Monist 69(4), 521-533.

Chelstrom, Eric (2013). Social Phenomenology: Husserl, Intersubjectivity, and Collective Intentionality. Lanham et al.: Lexington.

Chelstrom, Eric. 2016. Gurwitsch and the Role of Emotion in Collective Intentionality. In The Phenomenology of Sociality. Discovering the ' $W e$ ', ed. Thomas Szanto, and Dermot Moran, 248-262. London: Routledge.

Collin, Finn (1997). Social Reality. London, New York: Routledge.

Collins, Randall. 2004. Interaction Ritual Chains. Princeton: Princeton University Press.

Crowell, Steven (2012). Why is Ethics First Philosophy? Levinas in Phenomenological Context. European Journal of Philosophy 23(3), 564-588.

Davies, Martin, \& Stone, Tony (Eds.) (1995a). Folk Psychology: The Theory of Mind Debate. Oxford: Blackwell. 
Davies, Martin, \& Stone, Tony (Eds.) (1995a). Mental Simulation: Evaluations and Applications. Oxford: Blackwell.

De Jaegher, Hanne, Di Paolo, Ezequiel, \& Gallagher, Shaun (2010). Can Social Interaction Constitute Social Cognition? Trends in Cognitive Sciences 14(10), 441-447.

De Vignemont, Frédérique, and Pierre Jacob (2012). What Is It like to Feel Another's Pain? Philosophy of Science 79(2), 295-316.

Dolezal, Luna (2015). The Body and Shame: Phenomenology, Feminism, and the Socially Shaped Body. Lanham: Lexington.

Eilan, Naomi, Hoerl, Christoph \& Roessler, Johannes (Eds.) (2005). Joint Attention: Communication and Other Minds. Oxford: Oxford University Press.

Ferguson, Harvie (2006). Phenomenological Sociology: Insight and Experience in Modern Society: Experience and Insight in Modern Society. London: Sage.

Fuchs, Thomas (forthcoming). Intercorporeality and Interaffectivity. In Intercorporeality: Emerging Socialities in Interaction. Ed. C. Meyer, J. Streeck, and S. Jordan. Oxford University Press.

Fuchs, Thomas, \& De Jaegher, Hanne (2009). Enactive Intersubjectivity: Participatory Sense-making and Mutual Incorporation. Phenomenology and the Cognitive Sciences 8(4), 465-486.

Gallagher, Shaun (2008a). Direct Perception in the Intersubjective Context. Consciousness and Cognition 17(2), 535-543.

Gallagher, Shaun (2008b). Inference or Interaction: Social Cognition Without Precursors, Philosophical Explorations 11(3), 163-174.

Gallese, Vittorio (2001). The 'shared manifold' Hypothesis: From Mirror Neurons to Empathy. Journal of Consciousness Studies 8(5-7), 33-50.

Gilbert, Margaret (1989). On Social Facts. London/New York: Routledge.

Gilbert, Margaret (2002). Collective Guilt and Collective Guilt Feelings. The Journal of Ethics 6(2), 115-143.

Gilbert, Margaret (2006). A Theory of Political Obligation: Membership, Commitment, and the Bonds of Society. Oxford: Oxford University Press.

Gilbert, Margaret (2014). How we Feel: Understanding Everyday Collective Emotion Ascription. In Collective emotions. Perspectives from Psychology, and Sociology. Ed. C. v. Scheve, \& M. Salmela. Oxford: Oxford University Press.

Goldman, Alvin I. (2006). Simulating Minds: The Philosophy, Psychology, and Neuroscience of Mindreading. Oxford: Oxford University Press.

Gopnik, Alison, and Wellman, Henry M. (1992) Why the child's theory of mind really is a theory. Mind \& Language 7 (1-2), 145-171.

Gordon, Robert M. (2008). Beyond Mindreading. Philosopbical Explorations 11(3), 219_ 222.

Gubser, Michael (2014). The Far Reaches. Phenomenology, Ethics and Social Renewal in Central Europe. Stanford: Stanford University Press.

Guerrero, Sánchez H. A. (2016). Feeling Together and Caring with One Another: A Contribution to the Debate on Collective Affective Intentionality. Dordrecht: Springer. 
Gurwitsch, Aaron (1931 [1979]). Human Encounters in the Social World, transl. F. Kersten, Pittsburgh: Duquesne University Press. [Orig.: Die mitmenschlichen Begegnungen in der Milieunelt. Berlin: de Gruyter 1977.]

Jacob, Pierre (2011). The Direct-Perception Model of Empathy: A Critique. Review of Philosophy and Psychology 2(3), 519-540.

Jardine, James, \& Szanto, Thomas (2017). Empathy in the Phenomenological Tradition. In The Routledge Handbook of Empathy, ed. H. Maibom. London, New York: Routledge.

Hatfield, Elaine, Carpenter, Megan, and Rapson, Richard L. 2014. Emotional Contagion as a Precursor to Collective Emotions. In Collective emotions. Perspectives from Psychology, and Sociology, ed. Christian von Scheve, and Mikko Salmela, 108-122. Oxford: Oxford University Press.

Heal, Jane (1995). How to think about thinking. In: M. Davies, \& T. Stone (Eds.) (1995). Men-tal Simulation. Oxford: Blackwell.

Heidegger, Martin (1927) [1967]. Sein und Zeit. Tübingen: Niemeyer. [Engl.: Being and Time. Transl. by J. Macquarrie, \& E. Robinson. Oxford: Blackwell.]

Hildebrand, Dietrich von (1930). Metaphysik der Gemeinschaft. Augsburg: Haas \& Grabherr.

Husserl, Edmund (1908-1937 [2013]: Grensprobleme der Phänomenologie. Analysen des Unbewusstseins und der Instinkte. Metaphysik. Späte Ethik. Texte Aus dem Nachlass (1908-1937). Ed. By Rochus Sowa \& Thomas Vongehr. Dordrecht: Springer.

Husserl, Edmund (1916-1937 [2008]). Die Lebenswelt: Auslegungen der vorgegebenen Welt und ibrer Konstitution. Texte aus dem Nacblass (1916-1937). Ed. by Rochus Sowa. Dordrecht: Springer.

Husserl, Edmund (1929-1934 [2006]). Späte Texte über Zeitkenstitution (1929-1934). Die CManuskripte. Ed. by Dieter Lohmar. Heidelberg et al.: Springer.

Husserl, Edmund (1928-1935 [1973]). Zur Phänomenologie der Intersubjektivität. Texte aus dem Nachlaß. Dritter Teil: 1928-1935. Ed. by Iso Kern. Den Haag: Nijhoff.

Husserl, Edmund (1921-1928 [1973]: Zur Phänomenologie der Intersubjektivität. Texte aus dem Nacblaß. Zweiter Teil: 1921-1928. Ed. by Iso Kern. Den Haag: Nijhoff.

Husserl, Edmund (1905-1920 [1973]). Zur Pbänomenologie der Intersubjektivität. Texte aus dem Nachlaß. Erster Teil: 1905-1920. Ed. by Iso Kern. Den Haag: Nijhoff.

Husserl, Edmund (1923-1924 [1959]). Erste Philosopbie (1923/24). Zweiter Teil: Theorie der phänomenologischen Reduktion. Ed. by Rudolf Boehm. Den Haag: Nijhoff.

Husserl, Edmund (1954 [1970]). The Crisis of European Sciences and Transcendental Phenomenology. Transl. by D. Carr. Evanston: Northwestern University Press 1970. [Orig. Die Krisis der europäischen Wissenschaften und die transzendentale Phänomenologie. Eine Einleitung in die phänomenologische Philosophie. Ed. by Walter Biemel. Den Haag: Nijhoff.]

Husserl, Edmund (1912-1916 [1989]). Ideas pertaining to a pure phenomenology and to a phenomenological philosophy. Second book Studies in the phenomenology of constitution, transl. R. Rojcewicz \& A. Schuwer, Dordrecht: Kluwer. [Germ. Orig.: Ideen zu einer reinen Pbänomenologie und phänomenologischen Philosophie. Zweites Buch: Phänomenologische Untersuchungen zur Konstitution, ed. M. Biemel, The Hague: Nijhoff 1952.] 
Husserl, Edmund (1950). Cartesianische Meditationen. Eine Einleitung in die Phänomenologie. Ed. by Stephan Strasser Den Haag: Nijhoff. [Engl.: Cartesian Meditations: An Introduction to Phenomenology. Transl. D. Cairns. The Hague: Nijhoff 1977.]

Husserl, Edmund (1923). Wert des Lebens. Wert der Welt. Sittlichkeit (Tugend) und Glückseligkeit <Februar 1923>. Husserl Studies 13(3): 201-235.

Husserl, Edmund (1915-1917 [2016]): Ideen zu einer reinen Phänomenologie und phänomenologischen Philosophie. Zweites Buch: Phänomenologische Untersuchungen zur Konstitution und Wissenschaftstheorie (New Ed.) ed. by D. Fonfara, Dordrecht: Springer.

Illouz, Eva (2007). Cold Intimacies. The Making of Emotional Capitalism. Cambridge: Polity.

Kolnai, Aurel (1936 [2007]). Ekel, Hochmut, Haß: Zur Pbänomenologie feindlicher Gefüble. Berlin: Suhkamp.

Koo, Jo-Jo (2016). Early Heidegger on Social Reality. In The Phenomenological Approach to Social Reality, ed. Alessandro Salice, and Hans Bernhard Schmid, 91-119. Dordrecht: Springer.

Krueger, Joel (2016). The Affective 'We': Self-regulation and Shared Emotions. In The Phenomenology of Sociality: Discovering the 'We', ed. Thomas Szanto, and Dermot Moran, 263-277. London: Routledge.

Krueger, Joel, and Søren Overgaard (2012). Seeing Subjectivity: Defending a Perceptual Account of Other Minds. ProtoSociology 47, 239-262.

Krebs, Angelika. 2015. Zwischen Ich und Du. Eine dialogische Philosophie der Liebe. Berlin: Suhrkamp.

León, Felipe, and Zahavi, Dan. 2016. Phenomenology of Experiential Sharing: The Contribution of Schutz and Walther. In The Phenomenological Approach to Social Reality, ed. Alessandro Salice, and Hans Bernhard Schmid, 219-236. Dordrecht: Springer.

León, Felipe, Thomas Szanto, and Zahavi, Dan. (under review). Emotional Sharing and the Extended Mind. Synthese.

Leslie, Alan M. (1987). Pretense and Representation: The Origins of 'Theory of Mind'. Psycho-logical Review 94(4), 412-426.

Leslie, Alan M., Friedman, Ori, \& German, Tim P. (2004). Core Mechanisms in 'Theory of Mind'. Trends in Cognitive Sciences 8 (12), 528-533.

Lipps, Theodor (1907). Das Wissen von fremden Ichen. In Psychologische Untersuchungen I, Leipzig: Engelmann.

Lipps, Theodor ( (1909). Leiffaden der Psychologie, Leipzig: Verlag von Wilhelm Engelmann.

List, Christian, and Pettit, Philip (2011). Group Agency. The Possibility, Design, and Status of Corporate Agents. Oxford, New York: Oxford University Press.

Litt, Theodor. 1919. Individuum und Gemeinschaft. Grundfragen der sozialen Theorie und Ethik. Leipzig, Berlin: Teubner.

Natanson, Maurice (Ed.) (1973). Phenomenology and the Social Sciences. Volume 1 \& 2. Evanston, Ill.: Northwestern University Press.

Nichols, Shaun, and Stich, Stephen P. (2003). Mindreading. An Integrated Account of Pretence, Self-Awareness, and Understanding Other Minds. Oxford: Oxford University Press.

Meltzoff, Andrew N., and A. Gopnik, Alison (1993). The role of imitation in understanding per-sons and developing theories of mind. In Understanding other minds: 
Perspectives from autism, ed. S. Baron-Cohen, \& H. Tager-Flusberg. Oxford: Oxford University Press.

Merleau-Ponty, Maurice (1955 [1973]). Adventures of the Dialectic. Evanston, Ill.: Northwestern University Press.

Miettinen, Timo (2014). Transcendental Social Ontology. In Phenomenology and the Transcendental, ed. S. Heinämaa, M. Hartimo \& T. Miettinen: (pp. 147-171). London: Routledge.

Mulligan, Kevin (2016). Persons and Acts: Collective and Social. From Ontology to Politics. In The Phenomenological Approach to Social Reality, ed. Alessandro Salice, and Hans Bernhard Schmid, 17-45. Dordrecht: Springer.

Mulligan, Kevin (2001). Phenomenology: Philosophical Aspects. International Encyclopedia of the Social and Behavioral Sciences (pp. 11363-11369). Oxford: Pergamon.

Mulligan, Kevin (Ed.) (1987). Speech Act and Sachverbalt: Reinach and the Foundations of Realist Phenomenology. Dordrecht: Kluwer.Oksala, Johanna (2012). Poststructuralism: Michel Foucault. In The Routledge Companion to Phenomenology, ed. S. Luft, and S. Overgaard, London, New York: Routledge.

Overgaard, Søren, \& Zahavi, Dan (2009). Phenomenological sociology. In Encountering the everyday: An introduction to the sociologies of the unnoticed, ed. M. H. Jacobsen, 93-115. Palgrave Macmillan.

Otaka, Tomoo (1932). Grundlegungen der Lehre vom sozialen Verband. Wien: Julius Springer.

Paci, Enzo (1963). The Function of the Sciences and the Meaning of Man. Transl. by P. Piccone, \& J. E. Hansen. Evanston, Ill. Northwestern University Press. 1972.

Parkinson, Brian, Fischer, Agneta H., \& Manstead, Antony S. R. 2005. Emotion in Social Relations: Cultural, Group, and Interpersonal Processes. New York: Psychology Press.

Pettit, Philip (1993). The Common Mind. An Essay on Psychology, Society and Politics. Oxford: Oxford University Press.

Pettit, Philip (2003). Groups with minds of their own. In Socializing Metaphysics, ed. F. Schmitt (pp. 167-193). New York: Rowman \& Littlefield.

Pettit, Philip (2014). Three Issues in Social Ontology. In Rethinking the Individualism-Holism Debate, ed. J. Zahle, \& F. Collin. Cham: Springer.

Ratcliffe, Matthew (2007). Retbinking Commonsense Psychology: A Critique of Folk Psychology, Theory of Mind and Simulation. London: Palgrave Macmillan.

de Rivera, Joseph, and Páez, Darío. 2007. Emotional Climate, Human Security, and Cultures of Peace. Journal of Social Issues 63(2): 233-253.

Rimé, Bernard. (2009). Emotion Elicits the Social Sharing of Emotion: Theory and Empirical review. Emotion Review 1(1): 60-85.

Salice, Alessandro (2013). Social Ontology as Embedded in the Tradition of Realist Phenomenology. In The Background of Social Reality, ed. by M. Schmitz, B. Kobow, \& H. B. Schmid. Dordrecht: Springer.

Salice, Alessandro (2016). Love and other Social Stances. In The Phenomenology of Sociality: Discovering the 'We', ed. Thomas Szanto, and Dermot Moran, London, New York: Routledge. 
Salmela, Mikko (2014). The Functions of Collective Emotions in Social Groups. In Institutions, Emotions, and Group Agents. Contributions to Social Ontology, ed. Anita Konzelmann Ziv, and Hand Bernhard Schmid, 159-176. Dordrecht: Springer

Salmela, Mikko, and Nagatsu, Michiru (2016a). How Does it Really Feel to Act Together? Shared Emotions and the Phenomenology of We-agency. Phenomenology and the Cognitive Sciences. doi: 10.1007/s11097-016-9465-z.

Salmela, Mikko, and Nagatsu, Michiru (2016b). Collective Emotions and Joint Action. Journal of Social Ontology 2(1): 33-57.

Sartre, Jean-Paul (1943) [2003]. Being and Nothingness: An Essay on Phenomenological Ontology. Transl. H. E. Barnes. London: Routledge.

Sartre, Jean-Paul (1960) [1991]. Critique of Dialectical Reason Volume 1: Theory of Practical Ensembles. London: Verso.

Schmalenbach, Hermann (1922). Die soziologisch Kategorie des Bundes. Dioskuren 1, 35-105.

Schmid, Hans Bernhard (2000). Subjekt, System, Diskurs: Edmund Husserls Begriff transzendentaler Subjektivität in sozialtheoretischen Bezügen. Dordrecht: Kluwer.

Schmid, Hans Bernhard (2005). Wir-Intentionalität. Kritik des ontologischen Individualismus und Rekonstruktion der Gemeinschaft. Freiburg/München: Alber.

Schmid, Hans Bernhard (2009). Plural action. Essays in philosophy and social science. Dordrecht: Springer.

Schmid, Hans Bernhard (2014). The feeling of being a group. Corporate Emotions and Collective Consciousness. In Collective Emotions. Perspectives from Psychology, and Sociology, ed. Christian von Scheve, and Mikko Salmela, 3-16. Oxford: Oxford University Press

Schmid, Hans Bernhard (forthcoming). Collective Emotions. In The Routledge Handbook of Collective Intentionality, ed. Kirk Ludwig, and Marija Jankovic. https://www.academia.edu/17270427/Collective_Emotions. Accessed 1. Aug. 2016.

Scheler, Max (1916). Der Krieg als Gesamterlebnis. In Politisch-Pädagogische Schriften. Gesammelte Werke, Vol. 4, Ed. by Manfred S. Frings. Bern: Francke 1982, 267-282.

Scheler, Max (1924). Probleme einer Soziologie des Wissens. In Versuche zu einer Soziologie des Wissens. Ed. M. Scheler. München: Duncker \& Humblot. In: 1-146. [Engl.: Problem of a Sociology of Knowledge. Transl. by M. S. Frings. London: Routledge \& Kegan Paul 1980.]

Scheler, Max. (3rd ed.) (1926b) [2005]. Wesen und Formen der Sympathie. Bonn: Bouvier. [Engl.: The Nature of Sympathy, transl. P. Heath. London: Routledge \& Kegan Paul 1954.]

Scheler, Max. (3rd ed.) (1926a) [1980]. Der Formalismus in der Ethik und die materiale Wertetbik. Neuer Versuch der Grundlegung eines ethischen Personalismus. Bern: Francke. [Engl. Formalism in Ethics and Non-Formal Ethics of V alues: A New Attempt Toward the Foundation of an Ethical Personalism, transl. M. S. Frings \& R. L. Funk, Evanston: Northwestern University Press 1973.]

Schilling, Chris (2012). The Body and Social Theory. London: Sage. 
Schmalenbach, Hermann (1922). Die soziologisch Kategorie des Bundes. Dioskuren 1, 35-105.

Schütz, Alfred (1932) [1967]. The Phenomenology of the Social World. Tansl. by G. Walsh, \& F. Lehnert. Evanston, Ill. Northwestern University Press. [Orig. Der sinnhafte Aufbau der sozialen Welt. Eine Einleitung in die verstehende Soziologie. Wien: Springer.]

Schütz, Alfred (1953 [1970]). "Husserl's Ideas volume II.” In: A. Schütz: Collected Papers III: Studies in phenomenological philosophy, pp. 15-39. The Hague: Nijhoff.

Schütz, Alfred (1957). Das Problem der transzendentalen Intersubjektivität bei Husserl. Philosophische Rundschau 5, 81-107.

Schütz, Alfred, \& Luckmann, Thomas (1967 [2003]). Strukturen der Lebenswelt. Konstanz: UVK Verlagsgesellschaft. [Engl.: The Structures of the Life-world, transl. R. M. Zaner \& H. Tristram Engelhardt, London: Heinemann 1974.]

Schutz, Alfred (1970). Reflections on the Problem of Relevance. New Have: Yale University Press.

Schweikard, David, and Schmid, Hans Bernhard (2013). Collective intentionality. Stanford Encyclopedia of Philosophy. http://plato.stanford.edu/entries/collectiveintentionality/ [Accessed: 13 July 2013].

Searle, John R. (1990). Collective Intentions and Actions. In Intentions in Communication. Ed. P. Cohen, J. Morgan, and M.E. Pollack. Cambridge, MA: MIT Press.

Searle, John R. (1995). The Construction of Social Reality. London: Penguin.

Searle, John R. (2010). Making the Social World. The Structure of Human Civilization. Oxford: Oxford University Press.

Seemann, Axel (Ed.) (2012). Joint Attention: New Developments in Psychology, Philosophy of Mind, and Social Neuroscience. Cambridge, MA, London: MIT Press.

Smart, Barry (1976). Sociology, Phenomenology and Marxian Analysis. A Critical Discussion of the Theory and Practice of a Science of Society. London: Routledge \& Kegan Paul.

Smith, Eliot R., Seger, Charles R., and Mackie, Diane M. (2007). Can emotions be truly group level? Evidence regarding four conceptual criteria. Journal of personality and social psychology, 93(3): 431-446.

Spiegelberg, Herbert (1982). The Phenomenological Movement, 3rd ed. The Hague: Nijhoff.

Stein, Edith (1917) [2008]. Zum Problem der Einfüblung. ESGA, Bd. 5. Wien: Herder. [Engl. On the Problem of Empathy. Transl. W. Stein. Washington, D.C.: ICS Publication 1989.]

Stein, Edith (1922) 2010]. Beiträge zur philosophischen Begründung der Psychologie und der Geisteswissenschaften. ESGA, Bd. 6. Wien: Herder. [Engl. Philosophy of Psychology and the Humanities. Transl. M. C. Baseheart, and M. Sawicki. Washington, D.C.: ICS Publication 2000.]

Steinbock, Anthony J. (1995). Home and beyond: Generative phenomenology after Husserl. Evanston, Ill.: Northwestern University Press.

Stets, Jan E., and Turner, Jonathan H. (Eds.) (2014). Handbook of the Sociology of Emotions, Vol. II. Dordrecht: Springer.

Stueber, Karsten (2006). Rediscovering Empathy: Agency, Folk Psychology, and the Human Sci22ences. Cambridge, MA, London: MIT Press. 
Sullivan, Gavin (2015). Collective Emotion. Social and Personality Psychology Compass 9(8): 383-393.

Szanto, Thomas (2015). Collective Emotions, Normativity and Empathy: A Steinian Account. Human Studies 38(4): 503-527.

Szanto, Thomas (2016a). Husserl on Collective Intentionality. In Social Reality: The Phenomenological Approach, ed. Alessandro Salice, and Hans Bernhard Schmid, 145-172. Dordrecht: Springer.

Szanto, Thomas (2016b). Collectivizing Persons and Personifying Collectives: Reassessing Scheler on Group Personhood. In The Phenomenology of Sociality. Discovering the 'We', ed. Thomas Szanto, and Dermot Moran, 296-312. London: Routledge.

Szanto, T. (forthcoming): The Phenomenology of Shared Emotions: Reassessing Gerda Walther. In: S. Luft, \& R. Hagengruber (Eds.): Woman Phenomenologists on Social Ontology. Dordrecht: Springer.

Szanto, T., Moran, D. (Eds.) (2015): Empatby and Collective Intentionality: The Social Philosophy of Edith Stein. (Special Issue): Human Studies 38(4).

Turner, Bryan S. (2008). The Body and Society: Explorations in Social Theory. 3rd ed. Sage.

Tönnies, Ferdinand. 1935 [1991]. Gemeinschaft und Gesellschaft. Grundbegriffe der reinen Soziologie. Darmstadt: Wissenschaftliche Buchgesellschaft.

Tuomela, R. (2013). Social ontology: Collective intentionality and group agents. Oxford: Oxford University Press.

Theunissen, Michael (1965). Der Andere. Studien zur Sozialontologie der Gegenwart. Berlin, New York: de Gruyter.

Tomasello, Michael (2014). A Natural History of Human Thinking. Cambridge, MA: Harvard University Press.

Trân Duc Thao (1951). Phénoménologie et matérialisme dialectique. Paris: Editions Minh Tan. [Engl.: Phenomenology and Dialectical Materialism. Transl. by D. J. Herman, \& D. V. Mo-rano. Dordrecht: Reidel 1986.]

Vendrell Ferran, Í. (2016). Affective Intentionality: Early Phenomenological Contributions to a New Phenomenological Sociology. In: T. Szanto, T., and D. Moran, D. (Eds.): The Phenomenology of Sociality. Discovering the "We", London, New York: Routledge.

Vierkandt, A. (21928). Gesellschaftslehre. Stuttgart: Ferdinand Enke.

Vischer, Rudolf (1873). Über das optische Formgefühl: Ein Beitrag zur Ästhetik. Leipzig: Hermann Credner.

von Scheve, C., \& Salmela, M. (Eds.) (2014). Collective Emotions. Perspectives from Psychology, and Sociology. Oxford: Oxford University Press.

Waldenfels, Bernard, Broekman, Jan M., \& Pažanin, Ante (Eds.) (1977ff.). Phänomenologie und Marxismus. 4 Vols. Frankfurt a.M.: Suhrkamp. [Engl. (Selection): Waldenfels, Bernhard, \& Broekman, Jan M. (Eds.): Phenomenology and Marxism. Transl. by J. C. Evans, Jr. London: Routledge 1984.]

Walther, G. (1923). Zur Ontologie der sozialen Gemeinschaften. Jabrbuch für Philosopbie und phänomenologische Forschung, 6, 1-158.

Weber, Max (1922) [2002]. Wirtschaft und Gesellschaft. Grundriß der verstehenden Soziologie. Tübingen: Mohr Siebeck [Engl. REF]. 
Wolff, Ernst (2012). Critical Theory. In The Routledge Companion to Phenomenology. Ed. S. Luft, and S. Overgaard, London, New York: Routledge.

Zahavi, D. (2001) [1988]. Husserl and Transcendental Intersubjectivity. A Response to the Linguistic-Pragmatic Critique. (trans. E. A. Behnke). Athens, OH: Ohio University Press.

Zahavi, D. (2011). Empathy and direct social perception: a phenomenological proposal. Review of Philosophy and Psychology, 2(3), 541-558.

Zahavi, D. (2014). Self and other: Exploring subjectivity, empathy, and shame. Oxford: Oxford University Press.

Zahavi, D. (2015). You, me, and we. The sharing of emotional experiences. Journal of Consciousness Studies, 22(1-2), 84-101.

Zahavi, D., \& Rochat, P. (2015). Empathy $\neq$ sharing: Perspectives from phenomenology and developmental psychology. Consciousness and Cognition, doi: 10.1016/j.concog.2015.05.008.

Zahavi, Dan. Forthcoming. Intersubjectivity, Sociality, Community. In Oxford Handbook of the History of Phenomenology, ed. Dan Zahavi. Oxford: Oxford University Press.

Zahavi, Dan, and Salice, Alessandro. Forthcoming. Phenomenology of the We: Stein, Walther, Gurwitsch. In The Routledge Handbook of Philosophy of the Social Mind, ed. Julian Kiverstein. London, New York: Routledge. 